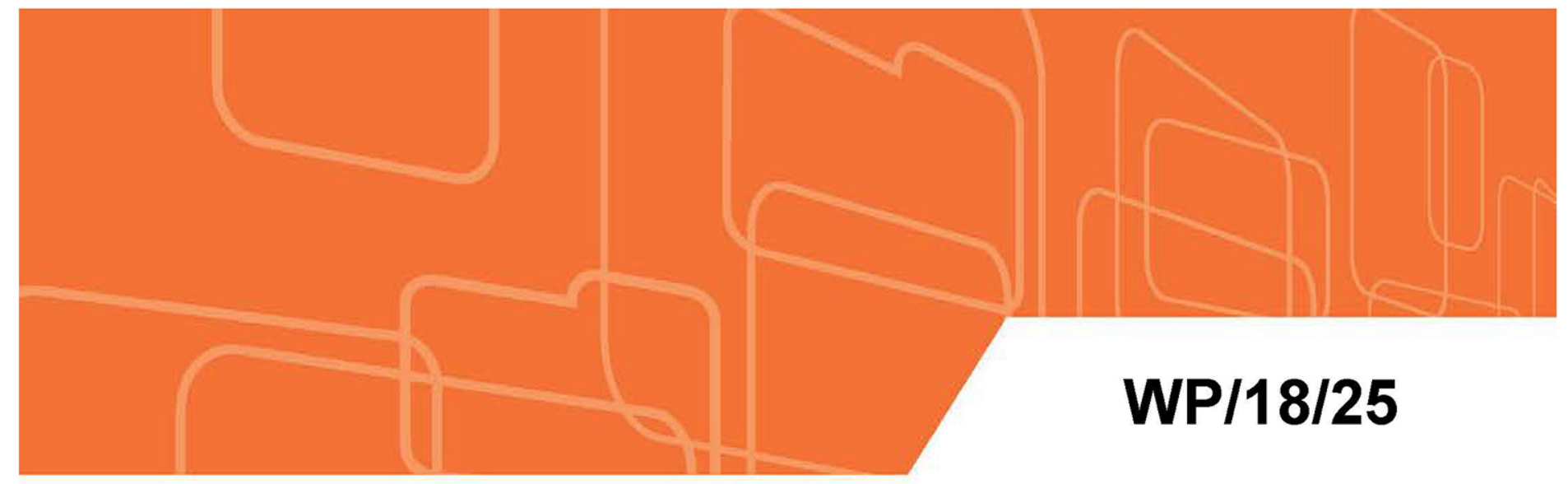

IMF Working Paper

\title{
Foreign Direct Investment and Women Empowerment: New Evidence on Developing Countries
}

by Rasmane Ouedraogo and Elodie Marlet

IMF Working Papers describe research in progress by the author(s) and are published to elicit comments and to encourage debate. The views expressed in IMF Working Papers are those of the author(s) and do not necessarily represent the views of the IMF, its Executive Board, or IMF management. 


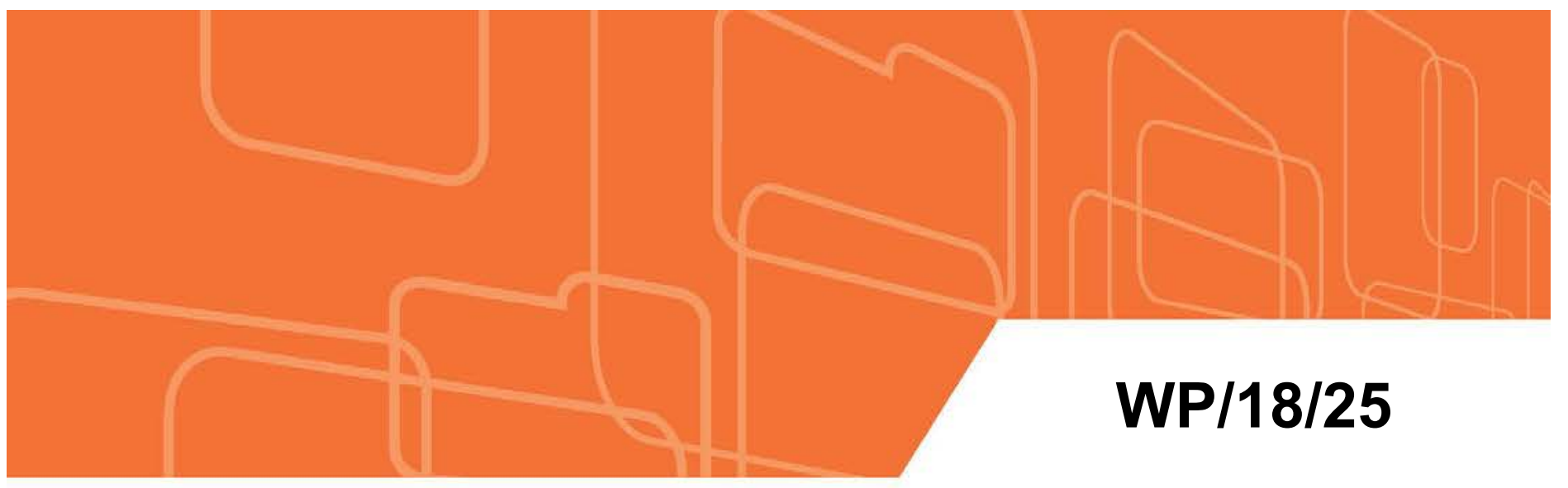

\title{
IMF Working Paper
}

\section{Foreign Direct Investment and Women Empowerment: New Evidence on Developing Countries}

\author{
by Rasmane Ouedraogo and Elodie Marlet
}

IMF Working Papers describe research in progress by the author(s) and are published to elicit comments and to encourage debate. The views expressed in IMF Working Papers are those of the author(s) and do not necessarily represent the views of the IMF, its Executive Board, or IMF management.

$$
\text { I N T E R N A T I O N A L M O N E T A R Y F U N D }
$$




\title{
IMF Working Paper
}

\author{
Statistics Department
}

\section{Foreign Direct Investment and Women Empowerment: New Evidence on Developing Countries Prepared by Rasmane Ouedraogo and Elodie Marlet ${ }^{1}$}

Authorized for distribution by Carlos Sánchez-Muñoz

December 2017

\begin{abstract}
IMF Working Papers describe research in progress by the author(s) and are published to elicit comments and to encourage debate. The views expressed in IMF Working Papers are those of the author(s) and do not necessarily represent the views of the IMF, its Executive Board, or IMF management.
\end{abstract}

\section{Abstract}

This paper assesses the effects of foreign direct investment (FDI) on gender development and gender inequality. In fact, FDI through increased labor demand, technological spillovers but mostly through corporate social responsibility and economic growth, can potentially influence women's welfare. Using a panel dataset of 94 developing countries from 1990 to 2015, we find that FDI inflows improve women's welfare and decrease gender inequality. However, the impact is lower in countries where women have low access to resources and face a heavier burden to open a business. This suggests that for countries to fully benefit from FDI inflows, they should ensure that women can enjoy free access to the labor market and associated income.

JEL Classification Numbers: F21, F63, J16, O10

Keywords: foreign direct investment, gender development, gender inequality

Author's E-Mail Address: rouedraogo@imf.org; emarlet@uw.edu

\footnotetext{
${ }^{1}$ The authors would like to thank Carlos Sánchez-Muñoz, Thomas Elkjaer, Monique Newiak, Jesmin Rahman, Claudia Berg and Suhaib Kebhaj, and participants at the Statistics Department Brown Bag Seminar Series for helpful discussions and comments. This paper was prepared while Elodie Marlet was a summer intern. Elodie Marlet is PhD student at Washington State University. Rasmane Ouedraogo is Economist in the Statistics Department-IMF.
} 


\section{Table of Contents}

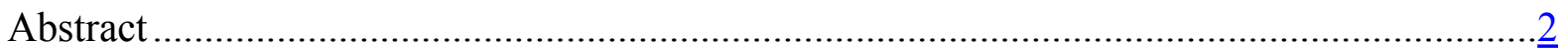

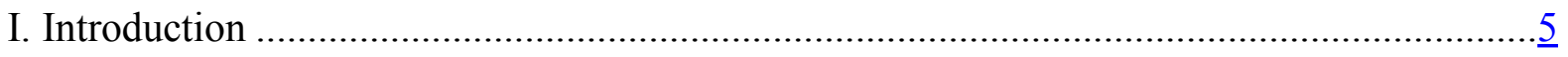

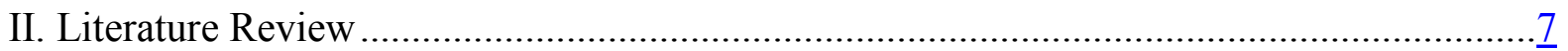

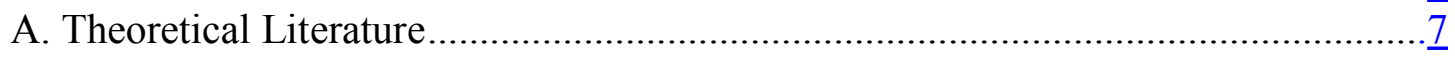

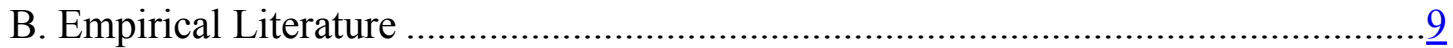

III. Data And Empirical Methodology..................................................................... 11

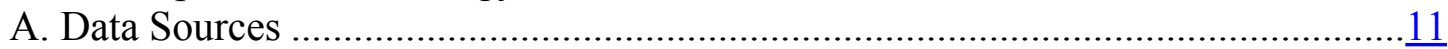

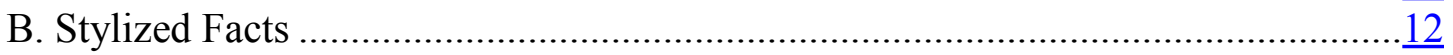

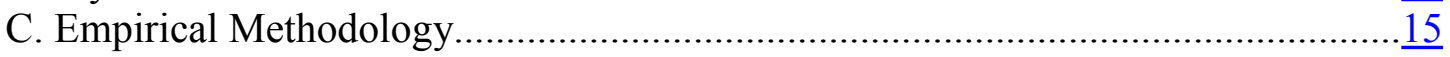

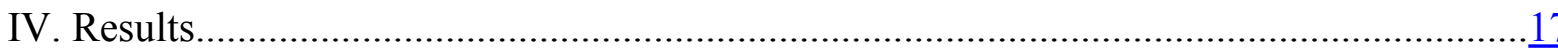

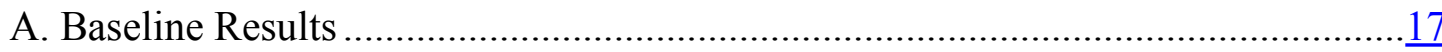

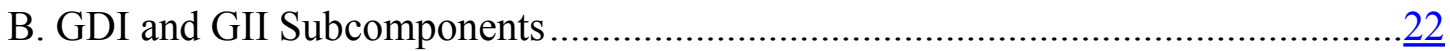

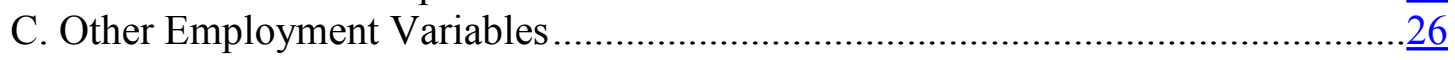

V. FDI Inflows And Gender Policies....................................................................

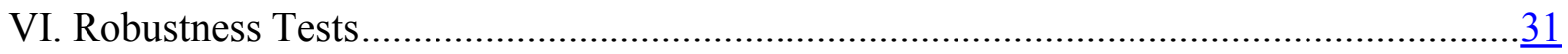

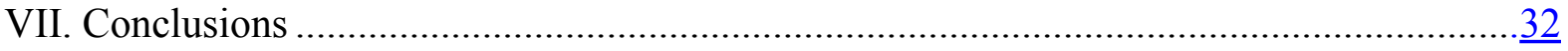

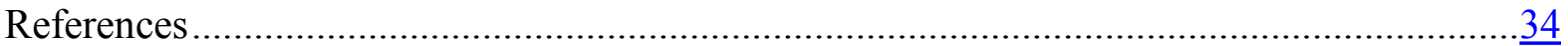

\section{Tables}

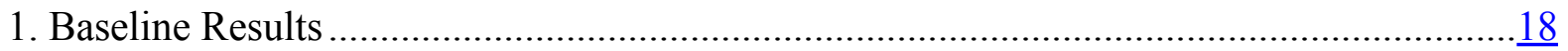

2. Baseline Results - Income Subgroups ..................................................................... 20

3. Baseline Results - Geographic Subgroups ............................................................. 21

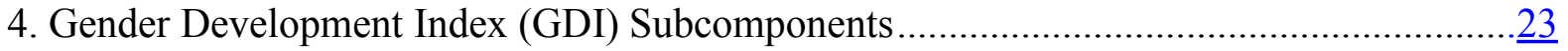

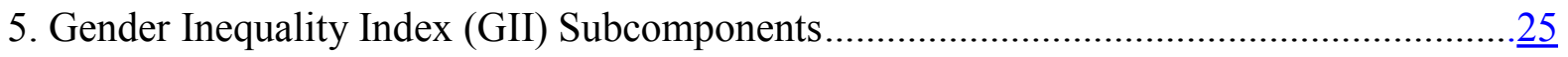

6. Using Other Gender Related Employment Variables .................................................27

7. FDI Inflows and Gender Policies............................................................................. 30

8. Robustness Checks: Using WEO and United Nations Data on FDI.............................. 41

9. Robustness Checks: Using Alternative Econometric Method ........................................ 42

10. Robustness Checks: Including Additional Control Variables ..................................... 43

11. Robustness Checks: Using FDI in Percentage of GDP Instead of FDI Per Capita ........... 44

12. Robustness Checks: Using Alternative Dependent Variables ....................................... 45 


\section{Figures}

Figure 1: FDI inflows, Gender Development Index, and Gender Inequality Index, 1990-2015

Figure 2. FDI Inflows, Gender Development Index, and Gender Inequality Index in Middle and Low Income Countries, 1990-2015 .........................................................................14 Figure 3. Log of Percentage Change in FDI, and Change in GDI and GII between 1990 and 2015 by Geographic Regions

\section{Appendixes}

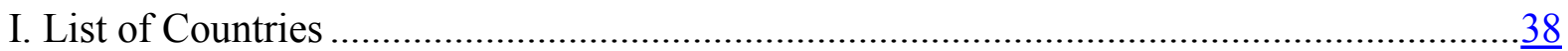

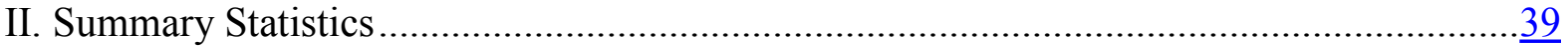

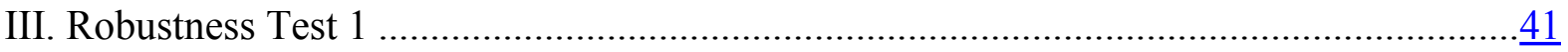

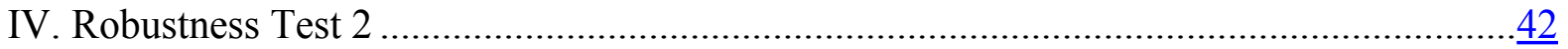

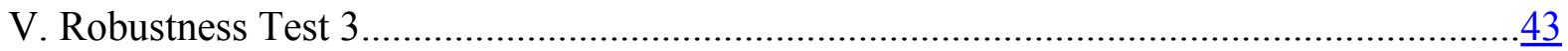

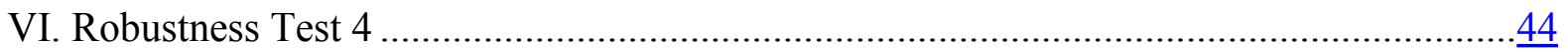

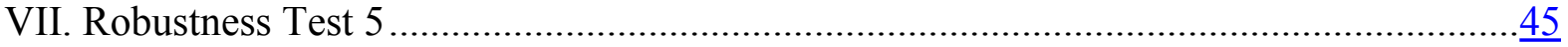




\section{INTRODUCTION}

Girls and women in developing countries still face great limitations and obstacles in their everyday lives. Girls have lower educational enrolment and completion rates than boys as parents tend to prioritize and allocate more resources to their sons' education. Also, in some countries, women are the targets of many violent acts and have low political participation rate and visibility. On another note, women allocate a greater share of their time than men to household chores and have lower labor market participation rates (United Nations, 2015). ${ }^{2}$ Working women are facing a persistent gender wage gap and discrimination within the work place. Improving women's welfare and decreasing those gender disparities is important not only for ethical and social reasons, but also from an economic perspective. It has been shown that increasing women's income can lead to a more efficient allocation of resources within households and increase the share of expenditures allocated to health, education, and nutrition (Chen, 2006; Björkman Nyqvist and Jayachandran, 2017; and Castilla and Walker, 2013).

Gender inequality has recently received considerable attention from policy makers, researchers and international organizations due to its crucial policy implications, as Christine Lagarde (IMF Managing Director) stated: "Globally, only 55 percent of women have the opportunity to participate in the labor force, compared with 80 percent for men. Women still earn about 50 percent less than men for the same type of work, and they represent only 20 percent of parliamentarians across the world". ${ }^{3}$ Numerous policy initiatives were created to help achieve greater equality and support research, such as EDGE (Evidence and Data for Gender Equality) from the United Nations Statistics Division and UN Women or Gender Budgeting database from the International Monetary Fund. Furthermore, research on this topic has expanded manifold to encompass fiscal policy studies to more microeconomic analysis of female bargaining power within the households (see for review Kochhar, Jain-Chandra, and Newiak, 2017; Stotsky, et al., 2016; Dieterich, Huang, and Thomas, 2016).

This study is part of a much broader body of literature analyzing the effect of foreign direct investment (FDI) on gender development and inequality. An important source of revenue for governments and capital for private firms, FDI is an engine of growth, which increases labor demand and households' income. As such, FDI can impact gender development and inequality through multiple transmission channels. First, FDI can expand firms and increase governments' revenue. Labor demand for women increases on an absolute level and the government has more resources to invest in public facilities and infrastructures that play an important role in women's empowerment (access to public schools or medical centers, water and electricity distribution...) (Braunstein, 2006). Second, if the majority of FDI is received

\footnotetext{
2 The United Nations, 2015, “The World's Women 2015”, Department of Economic and Social Affairs, United Nations, New York.

${ }^{3}$ Christine Lagarde, “The Business Case for Women's Empowerment”, November $18^{\text {th }} 2016$, APEC CEO Summit, Peru.
} 
in sectors that rely proportionally more on a female workforce, female labor demand will increase more than male labor demand and the labor participation rate gap will decrease (Aguayo-Tellez, et al., 2010). Third, multinational enterprises (MNEs) and majority-foreign owned firms bring in advanced technologies into their host countries, generating potential technological spillovers to local suppliers or customers. As local firms adapt and acquire new technology, they eventually give wage premiums to retain their newly trained workers (Glass and Saggi, 2002). Similarly, if the new technology is more attuned to a female workforce, female labor demand will increase (World Bank's World Development Report, 2012). Finally, some MNEs and majority-foreign owned firms establish a Corporate Social Responsibility (CSR) Initiative and some foreign investors can push to implement more gender equal norms (Abe, Javorcik, and Kodama, 2016; Olcott and Oliver, 2014; and Kucera, 2001). On the other hand, some studies have shown that foreign direct investment could have a negative impact on gender development and inequality under specific conditions: for instance, if national cultural norms are opposed to female development (Kwok and Tadesse, 2006) or if investments are made in technologically advanced sectors (Tejani and Milberg, 2010).

The paper differs from previous literature in three ways. First, most existing papers focused on a singular indicator of women's welfare, such as labor force participation or the gender wage gap. In contrast, we use two composite gender indices created by the United Nations Development Program (UNDP): the Gender Inequality Index (GII) and the Gender Development Index (GDI). These two indicators are more broad-based and encompass several gender related variables that are important for policy making decisions. Second, we look at two gender dimensions: gender development and gender inequality. Previous papers only focused on one specific indicator of either gender development (such as women's years of schooling) or gender inequality (mainly the gender wage gap or the labor participation rate gap). By restraining the outcomes of interest, such studies only offered limited scope for analysis. Third, we are the first, to the extent of our knowledge, to assess whether some recent and debated gender policies alter the impact of FDI on gender development and inequality. We study not only the effect of equal wage law, non-discrimination in hiring law, gender budgeting programs but also female access to resources by interacting those variables with FDI inflows.

The study covers a panel of 94 developing countries over the period 1990-2015. We estimate two equations with a Seemingly Unrelated Regressions Equations method to control for the potential correlation between the GDI and the GII. Our results indicate that FDI inflows are positively associated with gender development (women are better off) and negatively correlated with gender inequality (hence decreasing gender disparities). Effects are stronger and more significant for middle income countries and specific geographic regions: Sub-Saharan Africa, Latin America, and Middle East and North Africa for example. Furthermore, decomposing the gender development and inequality indices and estimating the equations for each subcomponent indicate that FDI inflows affect particularly women's life expectancy and maternity mortality ratio, as well as the female-to-male ratio of gross 
enrolment rate to the secondary level. Concerning employment, FDI inflows are negatively associated with female informal employment, female-to-male ratio of part-time employment in percentage of total employment, and the gender wage gap. Finally, the results show that the impact of FDI inflows on gender inequality depends on women's access to resources. Indeed, we find that FDI inflows increase gender disparities if women only have a restricted access to land and non-land assets, and to financial resources. The impact of FDI on gender issues is also reduced in countries where the number of procedures to open a business is higher for women than for men. Therefore, if countries want to benefit fully from FDI inflows, improving the business environment for women and access to resources need to be lifted so women can enjoy free access to the labor market and to new income.

Our paper is organized as follows. Section II provides a brief overview of the literature. Section III presents our data and exposes our empirical methodology. Section IV highlights the results, while Section V discusses the impact of gender policies. Section VI presents the robustness checks and Section VII concludes with some policy implications.

\section{LiteratURE REVIEW}

\section{A. Theoretical Literature}

The impact of FDI on gender development and inequality is ambiguous. On one hand, FDI can increase gender development and decrease gender inequality by increasing employment opportunities and wages of women workers thanks to good business practices by MNEs, general equilibrium effects, or simple spillovers to other firms and industries. On the other hand, FDI may have the opposite effect, by making local labor demand more elastic, and decreasing job security for women. Moreover, cultural and social norms barriers might severely hamper the effects of FDI in the recipient economy. A few studies and research papers focusing on the impact of FDI identified three main transmission channels through which FDI could affect gender outcomes.

\section{General Equilibrium Effect}

By expanding the pool of available financial capital, bringing in new technology, and improving the exports potential of recipient countries, FDI contributes to national economic development and allows for a potential increase in government revenue. A reinvestment of this extra revenue in public facilities and infrastructures (such as school construction) could improve women's welfare and decrease the gender educational gap (Braunstein, 2006). Additionally, the implementation of multinationals or the expansion of local firms increases female labor demand on an absolute and relative level. In fact, if most FDI is received in sectors whose labor workforce is primarily female, the labor demand is going to increase more for women than for men. The higher concentration of FDI towards more female intensive sectors could be explained by the Hecksher-Ohlin theory. As developing countries specialize in low-skilled and labor intensive sectors, developed countries specialize in more technologically advanced and capital intensive sectors. Since women's human capital is 
usually lower than men's in developing countries, they will be primarily affected by this type of specialization. On the other hand, FDI inflows in a male dominated sector (such as farming) can increase the gender wage gap. On another note, the gender wage gap could also decrease since it is becoming increasingly expensive for firms to discriminate in an environment of increased competition. Hence firms with the lowest costs will price out the discriminating firms according to Becker's theory (1971). In Mexico, Aguayo-Tellez and others (2010) noted that trade liberalization policies were positively correlated to the growth of female intensive sectors (e.g., clothing) and to the decline of male intensive industries (e.g., agriculture). The authors concluded that those changes improved the relative female to male labor participation rate ratio.

\section{Technological Spillovers}

MNEs are usually more productive and technologically advanced than domestic firms, and once established in a new market, some MNEs will partner with local firms upstream (suppliers of intermediate inputs) or downstream (customers). Those vertical relationships may create inter- and intra-industry technological spillovers as local partners are forced to adapt to the new technology (Glass and Saggi, 2002; Javorcik, 2004; Crespo and Fontoura, 2007; and Nelson et al., 2015). To adapt their inputs to the MNEs technology, local partners must not only adopt new technologies but also train their workforce and this could impact gender development and inequality in two ways. First, as described by Acemoglu (1998), women tend to work in different sectors of the economy than men and use different types of technologies. If the new technology brought in by FDI inflows is more complementary to the female workforce, MNEs and majority-owned foreign firms could prefer hiring more female than male workers, henceforth increasing female labor demand and decreasing the female to male labor participation rate ratio (World Bank's World Development Report, 2012).

Second, local firms could form and train their female workers to those new technologies and offer them a wage premium and greater job security (Glass and Saggi, 2002).

\section{Corporate Social Responsibility (CSR)}

Over the past decades, MNEs came under greater scrutiny and criticism by consumers and Non-Governmental Organizations (NGOs) over their impact on host countries' labor markets. To improve their image and reputation, some firms create a CSR initiative to signal their commitment to build and implement sustainable business practices in human resources

and labor standards. Those initiatives have been shown to improve working conditions, health and safety in the workplace (OECD, 2001). As source countries are often more gender equal than host economies, foreign investors can push for more gender equal norms and less discrimination. Thus, several studies have shown that majority-owned foreign firms are more likely to have a higher share of female directors, offer family-friendly working arrangements and have a lower gender wage gap (Kucera, 2001; Olcott and Oliver, 2014; and Abe, Javorcik and Kodama, 2016). Those practices can eventually spill over to local firms (UNCTAD, 2014; and Carr, 2016). 
A caveat from that analysis is that a country's culture and predominant religion could define whether FDI will have a meaningful impact on gender inequality (Kwok and Tadesse, 2006; and Carr, 2016). Even if a firm implements good practices with respect to its female workers' welfare, those practices might fail to spill in civil society due to cultural norms opposed to women's development. Furthermore, religion has an important role to play in gender development and inequality as Cooray and Potrafke (2011) find that gender inequality is not attributable to the absence of democracy but to culture and religion.

A second word of caution is driven by the apparent heterogeneity of FDI's effect on gender inequality across regions and industries. As developing countries begin their industrialization, they will attract FDI in low-skill intensive manufacturing sectors that hire mostly from the female labor force as women tend to be less educated and skilled than men. However, as the countries evolve on the industrialization path and move on to more technologically advanced types of manufactures, MNEs will hire a skilled male workforce. This creates an anti-female bias in labor demand as documented by Tejani and Milberg (2010) who found that trade liberalization increased female share of employment in manufacturing in developing countries but decreased it in developed countries.

\section{B. Empirical Literature}

Most empirical studies analyzing the impact of FDI on gender development and inequality use only one indicator of gender disparities, such as the gender wage gap or the labor force participation rate gap. This gives rise to mixed conclusions as the impact varies following the indicator of gender inequality used and the level of competitiveness of the host country.

The effect of FDI on gender wage gap is unclear. In her descriptive study, Davin (2004) showed that in export-oriented factories in Chinese export processing zones (EPZs), women workers earned more in a month than male workers from their home villages made in a year. A more analytical study by Rasekhi and Hosseinmardi (2012), using a panel regression with a sample of 21 developing countries from 2000 to 2007, found that FDI inflows reduced the gender wage gap. Yet, the authors warn that the gender wage gap could also widen as some firms only seek to benefit from female workers' lower wages and weaker bargaining power. This could explain the results from Vijaya and Kaltani (2007) who found that FDI inflows and FDI stocks in manufacturing sectors had a negative impact on female workers' wages in their fixed-effects panel analysis of 19 countries from 1987 to 2001.

Instead of the gender wage gap, several studies used the labor force participation rate gap as a proxy for gender inequality. In fact, a common argument found in the literature is that foreign direct investments generate employment opportunities for women. According to Seguino and Grown (2006), this happens for the following reasons. First, as described above, female workers represent most of the workforce in labor intensive industries, which are a main recipient of FDI in developing countries. Second, firms facing cost competition can take advantage of the lower wages in developing countries by opening factories in those 
countries and providing more job opportunities for women. However, increased competition from abroad and high capital mobility could make domestic labor demand more elastic and drive firms to cut their labor costs (Rodrick, 1997; and Seguino and Grown, 2006).

Nevertheless, Jaffri and others (2015) offered some nuanced insights as they expect FDI in technological and service sectors to have an ambiguous impact. In fact, FDI in more technical sectors require a skilled labor force and could widen the labor participation rate gap (as men are often more educated than women in developing countries), but they can also reduce the gender wage gap by increasing the returns of skilled women. However, Jaffri and others (2015) found that FDI in non-services sectors have a positive effect on female labor force participation.

The role of Corporate Social Responsibility Initiatives and the influence of foreign investors has also been studied in the literature. For example, Chen and others (2013) used Chinese firms census data from 2004 and found that foreign participation and export orientation within the same region and industry increase female labor workforce by 13 percent compared to non-export sectors reduce the gender wage gap and show no significant gender wage discrimination. Further evidence is brought by Kwok and Tadesse (2006); Olcott and Oliver (2014); Abe, Javorcik, and Kodama (2016); and Carr (2016). The latter two studies examined the effect of foreign ownership on gender-related employment outcomes in Japan. Results indicated that majority-owned foreign firms are more likely to have a higher share of female directors, have a lower gender wage gap and offer family-friendly working arrangements which are crucial for improving women's labor participation rate.

Other studies found that FDI had a positive impact on women's welfare. Anyanwu (2016) used cross-sectional time series and an ordinary least squares (OLS) estimation technique over the period 1991-2011 and found that a 1 percent growth in FDI in percentage of GDP increases gender equality in youth employment (proxied with the ratio of female to male employment for the age group 15-24) by 0.55 percentage point in all of Africa and by 0.44 percentage point in sub-Saharan Africa (SSA).

Our study departs in the following ways from the previous research. First, the majority of existing papers focuses only on a singular indicator of women's welfare, such as labor force participation or the gender wage gap. In contrast, we use two gender indices created by the United Nations Development Program (UNDP): the Gender Inequality Index (GII) and the Gender Development Index (GDI). The GII is composed of the maternal mortality ratio, adolescent birth rate, female and male population rate with at least secondary education, female and male shares of parliamentary seats, and female and male labor force participation rates. The GDI is composed of female and male life expectancy, expected and mean years of schooling, and the Gross National Income (GNI) per capita in purchasing power parity U.S. dollar. Using those two distinct indices will help us better assess women's welfare compared to the unidimensional gender variables used in previous research. We will also run the model with the different subcomponents of those two indices. 
Second, we look at the two dimensions of gender issues: gender development and gender inequality. Previous papers only focused on one specific indicator of either gender development (such as women's years of schooling) or gender inequality (mainly the gender wage gap and the labor participation rate gap). By restraining the outcomes of interest, such studies only offer limited scope for analysis. In fact, studying gender development without gender inequality and vice-versa severely limits the results interpretation. For example, if the gender wage gap is decreasing but women's education is not improving, the long-term impact on women's empowerment could be relatively weak. Hence, our paper allows for a comparative and simultaneous analysis of both gender development and inequality and their subcomponents which has not been done before.

Third, we are also the first, to the extent of our knowledge, to assess whether some recent and debated gender policies alter the impact of FDI on gender development and inequality. We not only study the effect of equal wage law, non-discrimination in hiring law, and gender budgeting programs, but also female access to resources by interacting those variables with FDI. Each of those policies can alter the local labor market in which multinationals are investing (equal wage and non-discrimination laws and gender budgeting) or improve women's access to the revenue generated by FDI (access to resources). Then analyzing those variables and how they influence the impact on FDI is very relevant and could have strong policy implications.

Fourth, we undertake various robustness tests by using FDI data from different sources, including the IMF's Balance of Payments database, IMF's World Economic Outlook, the World Bank's World Development Indicators, and UNCTAD database. We also use an alternative econometric method which allows us to address the problem of endogeneity.

\section{Data ANd Empirical Methodology}

\section{A. Data Sources}

We construct a comprehensive dataset of 94 developing countries, presented in Appendix A, from 1990-2015 covering the following regions: Sub-Saharan Africa (32 countries), Latin America and Caribbean (19), Europe and Central Asia (15), Middle-East and North Africa (11), South East Asia (6), and East Asia and Pacific (11). Furthermore, 69 of those countries are Lower or Upper Middle Income countries (MIC) and 25 are Low Income countries (LIC) according to IMF's World Economic Outlook classification. The data used in this paper are from various sources. We extracted the GDI and the GII from the United Nations Development Program. The GDI is an index ranging from 0 to 1 , with higher values indicating that women are better off. It measures disparities between women and men in three main dimensions: health (measured with life expectancy), knowledge (measured with expected and mean years of schooling), and living standards (measured with the GNI per capita). The computation of the index is explained in appendix. Our second dependent variable, the GII, is also a scale from 0 to 1 , with higher values indicating increased 
disparities between women and men. The index measures gender gap in three aspects of human life: reproductive health (maternity mortality ratio and adolescent fertility rate), empowerment (female share of parliamentary seats and educational attainment at the secondary level for women and men), and labor participation rate (for women and men aged 15 or older). Both indices are available for 188 countries from 1990-2015.

Our main explanatory variable is the inflow of foreign direct investments per capita extracted from the IMF's Balance of Payments' database. As a robustness test, we will vary our data source and use data from IMF's World Economic Outlook and the United Nations. Using FDI inflows per capita instead of the ratio to GDP allows us to avoid the potential endogeneity link between FDI inflows and GDP as FDI could increase GDP, and vice-versa (Alfaro and Volosovych, 2008). Hence, changes in the ratio of FDI per capita are more predictable than changes in the ratio of FDI to GDP and the impact from FDI per capita on GDI or GII will suffer less from unobservables. In addition, because population is more stable, expressing capital inflows in per capita terms allows us to capture their real dynamic, rather than GDP fluctuations. However, we will use FDI in percentage of GDP as a robustness test.

Finally, the data sources of our remaining control variables are presented in Appendix B, and include IMF's WEO database; the United Nations, the UNCTAD, the World Bank's database; the World Bank's Gender statistics database; ILO; UNESCO; Polity IV data series; and the OECD.

\section{B. Stylized Facts}

Figure 1 presents the relationship between FDI inflows per capita and gender development and inequality indices. We observe that foreign direct investments co-move with the gender development index and gender inequality index in developing countries. It appears that high levels of FDI inflows per capita are associated with higher values of gender development indices and with lower values of gender inequality indices, over the period 1990-2015. 
Figure 1: FDI inflows, Gender Development Index, and Gender Inequality Index, 1990-2015
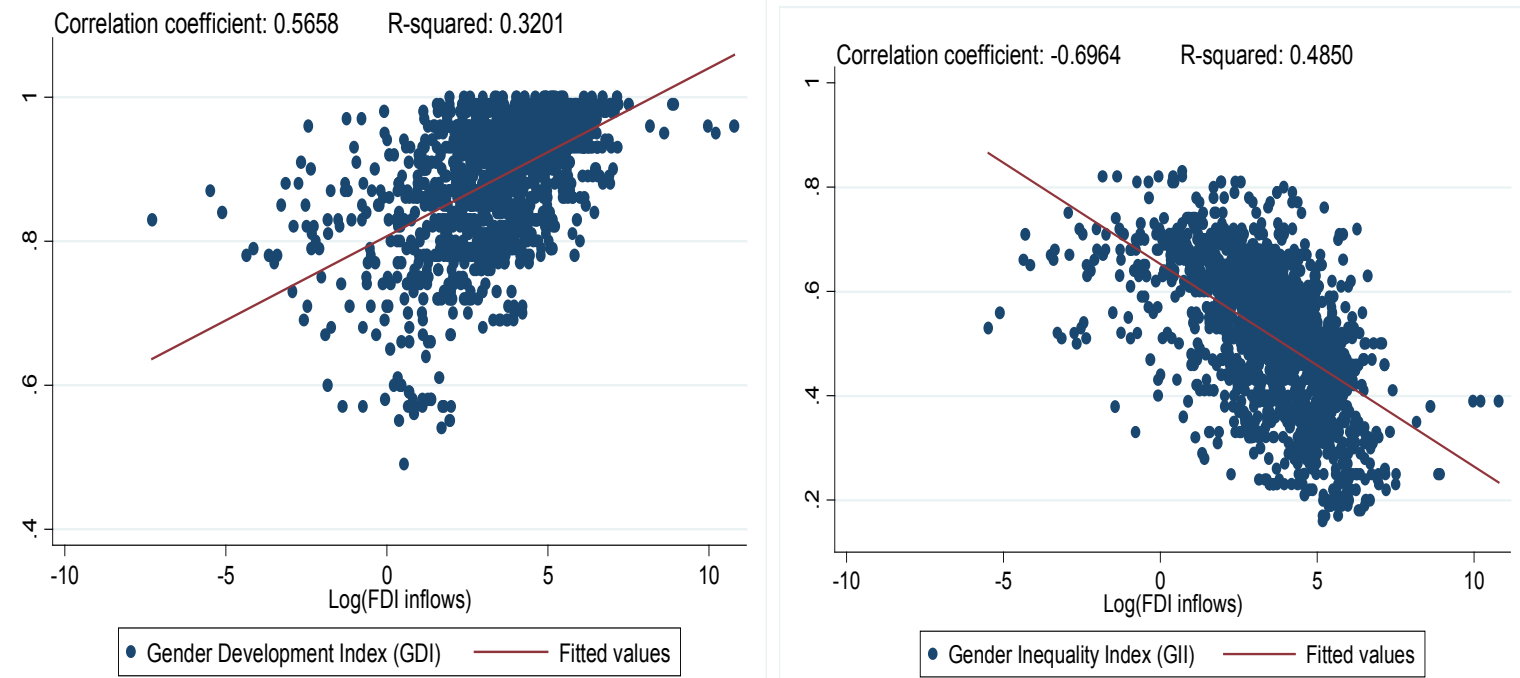

Source: IMF's Balance of Payments Database and authors' calculations

Decomposing our sample between middle and low income countries in Figure 2 reveals that FDI inflows per capita in middle-income countries seem to be more strongly positively related to GDI and more strongly negatively related to GII than FDI inflows in low-income countries. Consequently, it appears that the impact of FDI inflows on women's welfare and gender disparities is larger in middle income countries. Differences in the size of FDI inflows, technology, and absorption capacity could explain this observation. Indeed, middle-income countries may attract more FDI in services and manufacturing than low-income countries where FDI could be focused more in the primary sector (for instance in the mining and oil sectors). In fact, it has been shown that FDI in sectors that rely mostly on human physical capital and hire a majority of male workers, such as agriculture, could increase gender disparities (Vijaya and Kaltani, 2007; Tejani and Milberg, 2010; Juhn, et al., 2013; and Jaffri, et al., 2015). 
Figure 2. FDI Inflows, Gender Development Index, and Gender Inequality Index in Middle and Low Income Countries, 1990-2015

\subsection{Low income countries}
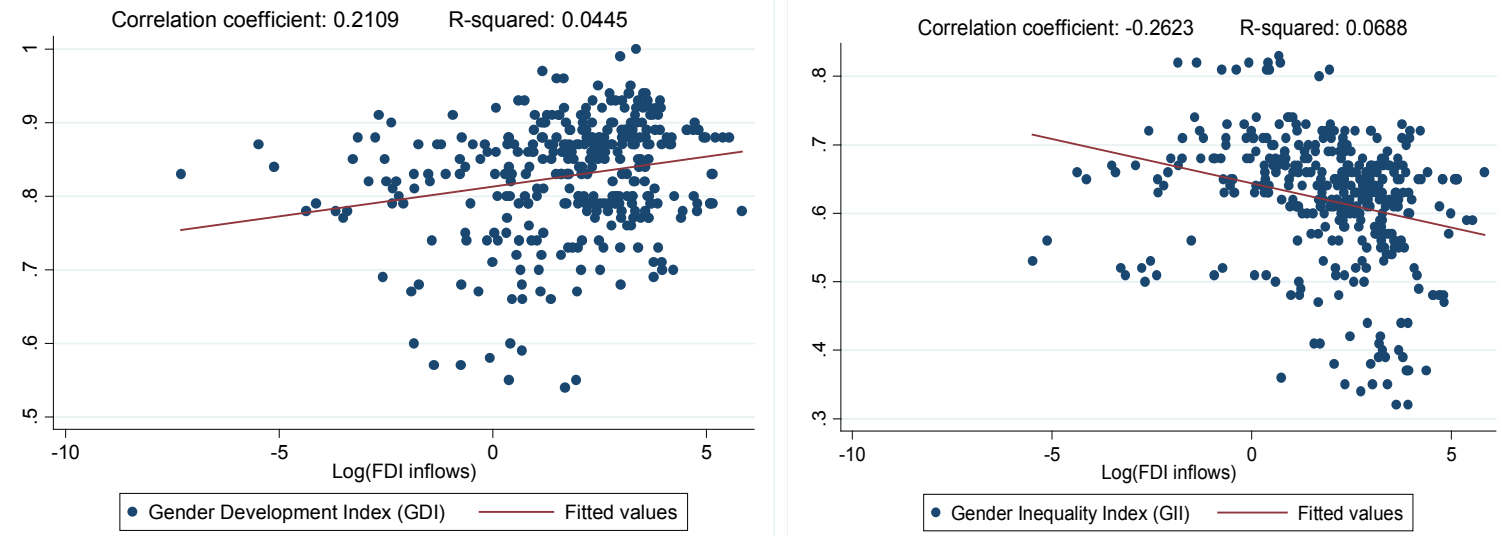

\subsection{Middle-income countries}
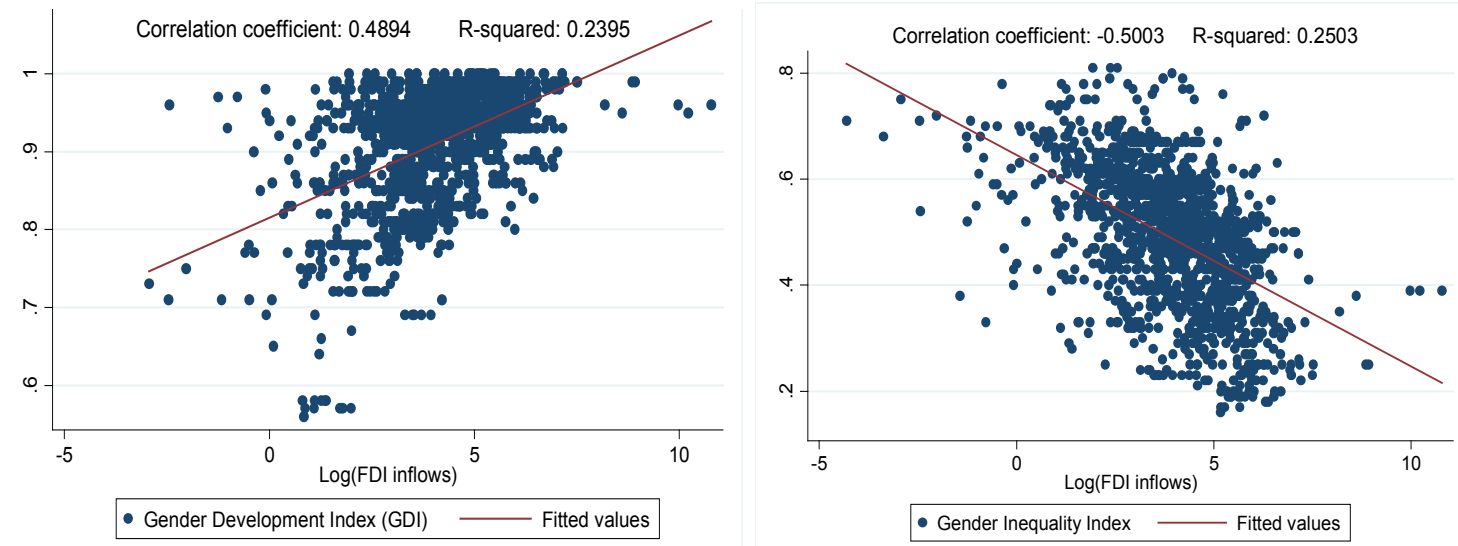

Source: IMF's STA and authors' calculations

Figure 3 presents the change in FDI inflows, gender development and gender inequality by geographic groups. In fact, between 1990 and 2015, the biggest increase in FDI inflows happened in Europe and Central Asia, Sub-Saharan Africa, and South East Asia. Meanwhile, South East Asia and Middle-East and North Africa experienced the biggest improvement in both women's welfare (GDI) (as the former increased by 0.15 points and the latter by 0.13 ) and the biggest decrease in gender disparities (GII) (as South East Asia's GII decreased by 0.20 points and Middle-East and North Africa's by 0.23 ). 


\section{Figure 3. Log of Percentage Change in FDI, and Change in GDI and GII between 1990 and 2015 by Geographic Regions}

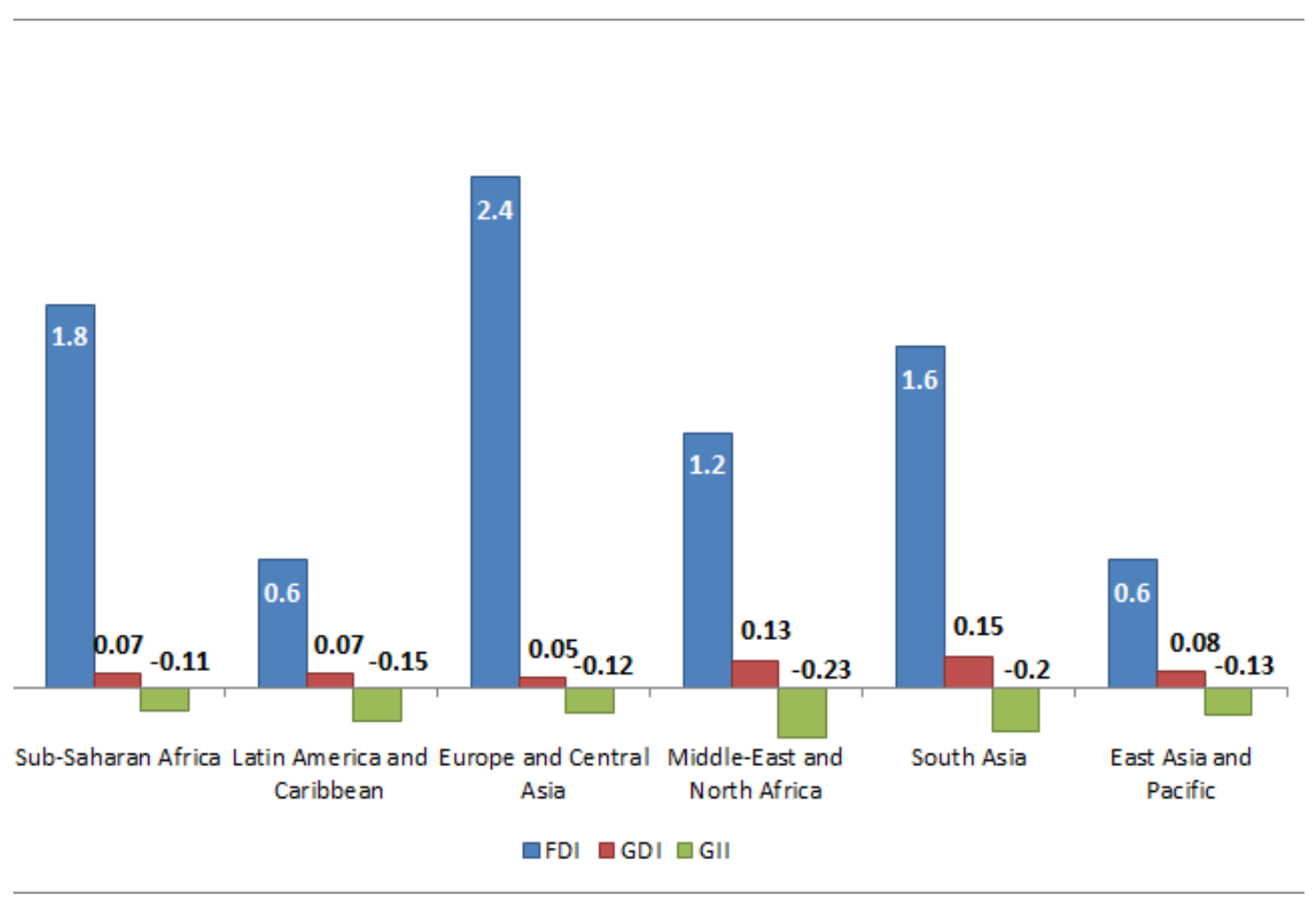

Source: IMF's STA, UNDP and authors' calculations

\section{Empirical Methodology}

We analyze the effects of FDI inflows per capita on both the GDI and the GII using the following simultaneous linear equations:

$$
\left\{\begin{array}{l}
G D I_{i, t}=\propto_{1}+\beta_{1} F D I_{i, t}+\theta_{1} X_{i, t}^{\prime}+v_{1 i}+\varphi_{1 t}+\varepsilon_{i, t} \\
G I_{i, t}=\propto_{2}+\beta_{2} F D I_{i, t}+\theta_{2} X_{i, t}^{\prime}+v_{2 i}+\varphi_{2 t}+u_{i, t}
\end{array}\right.
$$

Where FDI stands for foreign direct investment inflows per capita, GDI is gender development index and GII is gender inequality index. $v_{1,2 i}$ and $\varphi_{1,2 t}$ represent country-fixed effects and year-fixed effects, respectively. The fixed effects are included to control for unobservable variables differing across countries and common effects over time. $X^{\prime}{ }_{i, t}$ is a set of control variables including GDP growth, public debt in percentage of GDP, trade openness, quality of institutions, government expenditures in percentage of GDP, natural endowments in percentage of GDP, rural and female population. $t$ represents the time period and $i$ is the country. 
The system is estimated using a seemingly unrelated regression equations method to control for the correlation in contemporaneous cross-equation errors associated with the unrelated dependent variables. Women's development and gender inequality might depend on the same unobservables but also depend on each other as, for example, the less a girl goes to school (subcomponent of GDI), the less she will be able to participate in the labor market (GII subcomponent). The seemingly unrelated regression equations function as a Feasible Generalized Least Squares (FGLS). It first estimates the equations by OLS and uses the residuals to estimate the full variance-covariance matrix of the errors. Then it weights the estimates by the covariance of the residuals from the two regressions. As such, this method produces more efficient estimates than an OLS estimation, especially since our sample is rather large, and allows us to test joint-equation restrictions and perform joint tests. The following variables are included in the model: ${ }^{4}$

- Openness to trade indicator equal to trade (sum of exports and imports) to GDP ratio. This indicator allows us to isolate the effects of FDI inflows from the effects of other types of contacts with foreign firms. Anyanwu (2016) found that trade openness increased gender equality in youth employment, supporting the predictions of international trade theory that globalization could increase female employment in export sectors. Becker (1971) also predicted that trade expansion would lead to increased cost competition and less labor market discrimination. We then expect trade openness to increase the gender development index and to decrease the gender inequality index.

- Growth rate of GDP to account for the income effects. Economic growth is one of important sources of generating revenue for both men and women. We expect GDP growth to have a positive impact on gender development. Jönsson (2015), in her analysis of the effect of FDI on the female labor force participation, also control for countries' output level with GDP. She finds that an increase in GDP is associated with higher female labor force participation. This result supports Anyanwu (2016) who finds that growth in GDP per capita increases gender equality in youth employment.

- Polity 2 from the Polity IV data series. This variable indicates the level of democracy from the competitiveness and openness level of elections, political participation and the presence of checks on executive authority. Sound political institutions can increase the overall level of development in the country and democratic countries could encourage women's empowerment as suggested by the results of Neumayer and de Soysa (2011) who found that more democratic institutions increased women's economic and social rights.

\footnotetext{
${ }^{4}$ Descriptive summary statistics and data sources for all our variables are shown in appendix B.
} 
- General government total expenditures in percentage of GDP which can be taken as a proxy of expenditures in public infrastructures or social programs. Government spending can help promote gender development and decrease gender disparities, especially in health, education, and labor participation. This theory is supported by Anyanwu (2016) who found that higher government consumption expenditure increased gender equality in youth employment in North Africa.

- Total natural resources rents (sum of oil, natural gas, coal, mineral and forest rents) in percentage of GDP. The importance on resources rents could affect gender development through the eventual presence of corruption and the lack of production diversification. It can also impact the labor force participation rate gender differential as resources sectors rely on a skilled or highly physical workforce as noted by Tang and Zhang (2014), and Anyanwu (2016).

- General government gross debt in percentage of GDP as a high debt service could significantly hamper the government's capacity to invest in infrastructures or social programs such as welfare or child care, affecting both gender development and inequality. Furthermore, Fussell (2000) documented an increase in the labor force participation rate gap, as men entered the Maquiladora labor force following a debt crisis in Mexico.

- Rural population in percentage of total population. The higher the rural population, the more difficult it is the access to infrastructure and services. This can affect gender disparities in labor participation (as there could be more job opportunities for women in cities than in rural areas), but also affect gender development as public infrastructures might be less present in rural areas. Chen (2004) and Anyanwu (2016) highlight that it is more likely for women to enter the labor market in urban areas as the opportunity cost of working is higher in urban than in rural areas.

- Female population in percentage of total population could be an indicator of female empowerment if women represent the majority of the population. Hence, Anyanwu (2016) found that the ratio of female to male population increased gender equality in youth development.

\section{RESULTS}

\section{A. Baseline Results}

The baseline results presented in Table 1 indicate that FDI inflows are positively associated with gender development. The coefficient associated with FDI is strongly and positively correlated with GDI at 1 percent level (columns 1 and 3). That said, in developing countries, an increase in FDI inflows per capita indicates that women are 
becoming better off. As suggested in Section II, women's income could increase as FDI inflows bring more labor opportunities for female workers. This impact would be reinforced if investments are received in labor-intensive sectors that rely mostly on a female workforce (Aguayo-Tellez, et al., 2010; and Anyanwu, 2016) or if the new technology brought in by foreign investors allow firms to rely less on men's physical capital (Juhn, et al., 2013; and World Bank's World Development Report, 2012). As women enter the labor market and the households receive more income, they can allocate more resources to girls' education and women's health.

Furthermore, Table 1 presents evidence that FDI inflows are negatively associated with gender inequality. The coefficient associated with FDI is negatively and significantly correlated with the GII at 5 percent level (columns 2 and 4). Thus, across our panel, we find evidence that an increase in FDI inflows will on average decrease gender disparities between men and women. As foreign capital brings in new technology complimentary to female workforce, women's labor participation could increase more than men's (World Bank's World Development Report, 2012). Also, foreign investors can push for the adoption of more gender equal norms in their companies, such as no gender discrimination or family-friendly work arrangements, through CSR initiatives as highlighted by Kucera (2001); Olcott and Oliver (2014); and Abe, Javorcik, and Kodama (2016).

Table 1. Baseline Results

\begin{tabular}{|c|c|c|c|c|c|c|c|c|}
\hline & (1) & (2) & (3) & (4) & (5) & (6) & (7) & (8) \\
\hline Dependent variable & (GDI) & (GII) & $(\mathrm{GDI})$ & (GII) & (GDI) & (GII) & (GDI) & (GII) \\
\hline Log(FDI inflows) & $\begin{array}{l}0.00372 * * * \\
(0.0005)\end{array}$ & $\begin{array}{l}-0.00243^{* *} \\
(0.0009)\end{array}$ & $\begin{array}{l}0.00356^{* * *} \\
(0.0005)\end{array}$ & $\begin{array}{l}-0.00218^{* *} \\
(0.0009)\end{array}$ & & & & \\
\hline Log(FDI inflows), t-1 & & & & & $\begin{array}{l}0.00348 * * * \\
(0.000538)\end{array}$ & $\begin{array}{l}-0.00210^{* *} \\
(0.000954)\end{array}$ & $\begin{array}{l}0.00326 * * * \\
(0.000536)\end{array}$ & $\begin{array}{l}-0.00179 * \\
(0.000948)\end{array}$ \\
\hline GDP growth & $\begin{array}{l}0.00396 \\
(0.0050)\end{array}$ & $\begin{array}{l}0.0166^{*} \\
(0.0089)\end{array}$ & $\begin{array}{l}0.00635 \\
(0.0050)\end{array}$ & $\begin{array}{l}0.0136 \\
(0.0089)\end{array}$ & $\begin{array}{l}0.00272 \\
(0.00501)\end{array}$ & $\begin{array}{l}0.0135 \\
(0.00889)\end{array}$ & $\begin{array}{l}0.00433 \\
(0.00500)\end{array}$ & $\begin{array}{l}0.0104 \\
(0.00885)\end{array}$ \\
\hline Log(trade openness) & $\begin{array}{l}0.00879 * * * \\
(0.0029)\end{array}$ & $\begin{array}{l}0.00172 \\
(0.0053)\end{array}$ & $\begin{array}{l}0.0104^{* * * *} \\
(0.0030)\end{array}$ & $\begin{array}{l}-0.00394 \\
(0.0054)\end{array}$ & $\begin{array}{l}0.00856^{* * *} \\
(0.00303)\end{array}$ & $\begin{array}{l}0.000475 \\
(0.00537)\end{array}$ & $\begin{array}{l}0.0100^{* * *} \\
(0.00311)\end{array}$ & $\begin{array}{l}-0.00608 \\
(0.00551)\end{array}$ \\
\hline Polity2 & $\begin{array}{l}0.00101 * * * \\
(0.0003)\end{array}$ & $\begin{array}{l}-0.000812^{*} \\
(0.0004)\end{array}$ & $\begin{array}{l}0.000881 * * * \\
(0.0003)\end{array}$ & $\begin{array}{l}-0.000902 * * \\
(0.0005)\end{array}$ & $\begin{array}{l}0.00112 * * * \\
(0.000261)\end{array}$ & $\begin{array}{l}-0.000799 * \\
(0.000462)\end{array}$ & $\begin{array}{l}0.00101 * * * \\
(0.000262)\end{array}$ & $\begin{array}{l}-0.000908^{*} \\
(0.000463)\end{array}$ \\
\hline Log(public debt) & $\begin{array}{l}-0.00532^{* * *} \\
(0.0011)\end{array}$ & $\begin{array}{l}0.00491^{* *} \\
(0.0020)\end{array}$ & $\begin{array}{l}-0.00556^{* * * *} \\
(0.0011)\end{array}$ & $\begin{array}{l}0.00569 * * * \\
(0.0021)\end{array}$ & $\begin{array}{l}-0.00533 * * * \\
(0.00114)\end{array}$ & $\begin{array}{l}0.00483 * * \\
(0.00203)\end{array}$ & $\begin{array}{l}-0.00561 * * * \\
(0.00118)\end{array}$ & $\begin{array}{l}0.00569 * * * \\
(0.00208)\end{array}$ \\
\hline Female population & & & $\begin{array}{l}0.00388^{* * *} \\
(0.0017)\end{array}$ & $\begin{array}{l}-0.0110^{* * *} \\
(0.0031)\end{array}$ & & & $\begin{array}{l}0.00336^{*} \\
(0.00173)\end{array}$ & $\begin{array}{l}-0.0112 * * * \\
(0.00307)\end{array}$ \\
\hline Government expenditure & & & $\begin{array}{l}0.000658^{* * *} \\
(0.0001)\end{array}$ & $\begin{array}{l}0.000231 \\
(0.0003)\end{array}$ & & & $\begin{array}{l}0.000624^{* * *} \\
(0.000152)\end{array}$ & $\begin{array}{l}0.000220 \\
(0.000269)\end{array}$ \\
\hline Natural resources rents & & & $\begin{array}{l}-0.000231 \\
(0.0002)\end{array}$ & $\begin{array}{l}0.000875^{* * *} \\
(0.0003)\end{array}$ & & & $\begin{array}{l}-0.000185 \\
(0.000171)\end{array}$ & $\begin{array}{l}0.000956 * * * \\
(0.000303)\end{array}$ \\
\hline Rural population & & & $\begin{array}{l}-5.25 \mathrm{E}-05 \\
(0.0002)\end{array}$ & $\begin{array}{l}-0.000432 \\
(0.0004)\end{array}$ & & & $\begin{array}{l}4.24 \mathrm{e}-05 \\
(0.000252)\end{array}$ & $\begin{array}{l}-0.000554 \\
(0.000446)\end{array}$ \\
\hline Constant & $\begin{array}{l}0.585 * * * \\
(0.0156)\end{array}$ & $\begin{array}{l}0.656 * * * \\
(0.0278)\end{array}$ & $\begin{array}{l}0.377 * * * \\
(0.0857)\end{array}$ & $\begin{array}{l}1.235^{* * *} \\
(0.1520)\end{array}$ & $\begin{array}{l}0.526 * * * \\
(0.0168)\end{array}$ & $\begin{array}{l}0.824 * * * \\
(0.0298)\end{array}$ & $\begin{array}{l}0.340 * * * \\
(0.0862)\end{array}$ & $\begin{array}{l}1.424 * * * \\
(0.153)\end{array}$ \\
\hline Observations & 1,157 & 1,157 & 1,147 & 1,147 & 1,149 & 1,149 & 1,139 & 1,139 \\
\hline R-squared & 0.969 & 0.962 & 0.97 & 0.963 & 0.968 & 0.962 & 0.969 & 0.963 \\
\hline Country-fixed effects & YES & YES & YES & YES & YES & YES & YES & YES \\
\hline Year-fixed effects & YES & YES & YES & YES & YES & YES & YES & YES \\
\hline
\end{tabular}


Table 1 also shows that trade openness is positively and significantly associated with gender development. Trade openness could improve women's welfare by enticing more women to enter the labor market but also by bringing in more income to the government. However, it doesn't have any significant impact on gender inequality, contrary to Anyanwu (2016) who found that trade openness decreased gender inequality in youth employment. Government expenditures also appears to be positively correlated with gender development but doesn't have any significant effect on gender inequality. Our results support Anyanwu (2016) who found that higher government expenditure increased gender equality in youth employment in North Africa. Higher government expenditure could signal increased investments in social programs and public infrastructures which would help women's accessing the labor market.

Like FDI inflows, democratic institutions are found to be positively associated with gender development and negatively associated with gender inequality. Democratic countries could have greater human development in general but also encourage less gender inequality (Neumayer and de Soysa, 2011) and the inclusion of all citizens in civil society. Female population in percentage of total population is also found to be positively correlated with women's welfare and negatively correlated with gender inequality. It is possible that a greater share of women in the population increases women's visibility in the population and promotes greater women's empowerment (Anyanwu, 2016), but also orients the type of FDI received towards more female workforce sectors.

On the other hand, public debt and natural resources rents are positively associated with gender inequality. Natural resources sectors (agriculture, oil production) use predominantly a male workforce so greater natural resources rents could indicate lower female labor participation rate and higher gender income inequalities, as suggested by Tang and Zhang (2014) and Anyanwu (2016). Additionally, a higher gross debt in percentage of GDP can decrease the ability of the government to invest in social programs but also could signal economic hardship for households. As shown in Table 1, this could decrease women's welfare (GDI) and increase gender inequalities (GII) as households have less income to invest in education or health. Finally, the coefficients associated with GDP growth and the share of rural population are not statistically significant.

We then decompose our sample between low and middle-income countries to evaluate if the effect of FDI on gender development and inequality depends on the recipient country's income level. Table 2 shows that FDI inflows have a stronger impact on gender outcomes in middle-income countries than in low-income countries. In fact, FDI inflows have a more significant but also stronger impact on gender development in middle-income compared to low-income countries. Middle-income countries not only receive more FDI inflows per capita (signaling that effects on women's welfare could be higher on an absolute level) but also have a higher absorption capacity. However, this is tempered by the fact that the effects on gender inequality are similar in both subgroups. 
FDI inflows are found to decrease gender disparities the same way in middle-income and low-income countries. Low-income countries have a lower technological level than middle-income countries and receive more investments in medium- and low-tech manufacturing industries, which rely mostly on a female workforce (Jacob and Sasso, 2016).

Table 2. Baseline Results - Income Subgroups

\begin{tabular}{|c|c|c|c|c|}
\hline & (1) & $(2)$ & (3) & (4) \\
\hline & \multicolumn{2}{|c|}{ Middle Income Countries } & \multicolumn{2}{|c|}{ Low Income Countries } \\
\hline Dependent variables: & (GDI) & (GII) & (GDI) & (GII) \\
\hline \multirow[t]{2}{*}{ Log(FDI inflows) } & $0.00341 * * *$ & $-0.00309 * * *$ & $0.00193 *$ & $-0.00321 * * *$ \\
\hline & $(0.0006)$ & $(0.0012)$ & $(0.0010)$ & $(0.0011)$ \\
\hline \multirow[t]{2}{*}{ GDP growth } & 0.00233 & $0.0192 *$ & 0.0106 & -0.00104 \\
\hline & $(0.0053)$ & $(0.0104)$ & $(0.0154)$ & $(0.0158)$ \\
\hline \multirow[t]{2}{*}{ Log(trade openness) } & $0.00864 * * *$ & -0.00224 & -0.000843 & $0.0169 * * *$ \\
\hline & $(0.0033)$ & $(0.0066)$ & $(0.0058)$ & $(0.0059)$ \\
\hline \multirow[t]{2}{*}{ Polity2 } & $0.000772 * *$ & $-2.28 \mathrm{E}-05$ & $0.000825^{*}$ & $-0.00282 * * *$ \\
\hline & $(0.0003)$ & $(0.0006)$ & $(0.0005)$ & $(0.0005)$ \\
\hline \multirow[t]{2}{*}{$\log ($ public debt) } & $-0.00267 * *$ & $0.0108 * * *$ & $-0.00441 * *$ & $-0.0113^{* * *}$ \\
\hline & $(0.0013)$ & $(0.0025)$ & $(0.0022)$ & $(0.0023)$ \\
\hline \multirow[t]{2}{*}{ Constant } & $0.862 * * *$ & $0.394 * * *$ & $0.798 * * *$ & $0.638 * * *$ \\
\hline & $(0.0154)$ & $(0.0304)$ & $(0.0246)$ & $(0.0254)$ \\
\hline Observations & 910 & 910 & 253 & 253 \\
\hline R-squared & 0.965 & 0.953 & 0.966 & 0.977 \\
\hline Country-fixed effects & YES & YES & YES & YES \\
\hline Year-fixed effects & YES & YES & YES & YES \\
\hline
\end{tabular}

Furthermore, Table 3 below reveals that the effect of FDI inflows on gender differs across geographic regions. Indeed, the coefficient associated with FDI inflows and gender development is positive and significant for all geographic regions except South East Asia where the coefficient is negative. As described in Section II, this could be explained if the region receives a majority of FDI in technological sectors that hire predominantly a male workforce or in sectors that rely on human physical capital. Such investments may discourage women's labor participation and predominantly benefit male workers. In fact, Aguayo-Tellez (2011) recalled that South-East Asia experienced "“defeminization" of employment". As for gender inequality, the coefficient associated with FDI inflows is negative and statistically significant mainly in Europe and Central Asia, Middle-East and North Africa, and in East Asia and Pacific. 
Table 3. Baseline Results - Geographic Subgroups

\begin{tabular}{|c|c|c|c|c|c|c|c|c|c|c|c|c|}
\hline & $(1)$ & $(2)$ & (3) & $(4)$ & $(5)$ & $(6)$ & $(7)$ & $(8)$ & $(9)$ & $(10)$ & $(11)$ & $(12)$ \\
\hline Dependent variable & $(\mathrm{GDI})$ & $(\mathrm{GII})$ & $(\mathrm{GDI})$ & $(\mathrm{GII})$ & $(\mathrm{GDI})$ & (GII) & $(\mathrm{GDI})$ & (GII) & $(\mathrm{GDI})$ & (GII) & $(\mathrm{GDI})$ & $(\mathrm{GII})$ \\
\hline Region & SSA & SSA & Latin America & Latin America & $\begin{array}{c}\text { Europe \& } \\
\text { Central Asia }\end{array}$ & $\begin{array}{c}\text { Europe \& } \\
\text { Central Asia }\end{array}$ & $\begin{array}{c}\text { Middle East \& } \\
\text { North Africa }\end{array}$ & $\begin{array}{c}\text { Middle East \& } \\
\text { North Africa }\end{array}$ & South Asia & South Asia & $\begin{array}{c}\text { East Asia \& } \\
\text { Pacific }\end{array}$ & $\begin{array}{c}\text { East Asia \& } \\
\text { Pacific }\end{array}$ \\
\hline Log (FDI inflows) & $\begin{array}{l}0.00329 * * * \\
(0.0009)\end{array}$ & $\begin{array}{l}0.000935 \\
(0.0007)\end{array}$ & $\begin{array}{l}0.00230 * * \\
(0.0009)\end{array}$ & $\begin{array}{l}-0.000588 \\
(0.0017)\end{array}$ & $\begin{array}{l}0.00253^{*} \\
(0.0015)\end{array}$ & $\begin{array}{l}-0.0116^{* *} \\
(0.0051)\end{array}$ & $\begin{array}{l}0.00166^{* *} \\
(0.0006)\end{array}$ & $\begin{array}{l}-0.00677^{*} \\
(0.0036)\end{array}$ & $\begin{array}{l}-0.00744 * \\
(0.0039)\end{array}$ & $\begin{array}{l}0.006 \\
(0.0038)\end{array}$ & $\begin{array}{l}0.00212 * * * \\
(0.0007)\end{array}$ & $\begin{array}{l}-0.00388 * \\
(0.0021)\end{array}$ \\
\hline GDP growth & $\begin{array}{l}0.00626 \\
(0.0117)\end{array}$ & $\begin{array}{l}-0.00552 \\
(0.0089)\end{array}$ & $\begin{array}{l}-0.0107^{*} \\
(0.0060)\end{array}$ & $\begin{array}{l}0.00228 \\
(0.0107)\end{array}$ & $\begin{array}{l}0.0107 \\
(0.0085)\end{array}$ & $\begin{array}{l}0.0185 \\
(0.0294)\end{array}$ & $\begin{array}{l}-0.0197 * * \\
(0.0077)\end{array}$ & $\begin{array}{l}0.0612 \\
(0.0417)\end{array}$ & $\begin{array}{l}0.0623 \\
(0.0458)\end{array}$ & $\begin{array}{l}-0.0794 * \\
(0.0446)\end{array}$ & $\begin{array}{l}0.0034 \\
(0.0078)\end{array}$ & $\begin{array}{l}0.0176 \\
(0.0242)\end{array}$ \\
\hline Log(trade openness) & $\begin{array}{l}0.0162 * * * \\
(0.0061)\end{array}$ & $\begin{array}{l}-0.00472 \\
(0.0047)\end{array}$ & $\begin{array}{l}0.00165 \\
(0.0043)\end{array}$ & $\begin{array}{l}-0.0212 * * * \\
(0.0075)\end{array}$ & $\begin{array}{l}-0.0074 \\
(0.0054)\end{array}$ & $\begin{array}{l}0.0137 \\
(0.0187)\end{array}$ & $\begin{array}{l}-0.0103 * \\
(0.0060)\end{array}$ & $\begin{array}{l}0.0358 \\
(0.0326)\end{array}$ & $\begin{array}{l}0.0457 * * * \\
(0.0120)\end{array}$ & $\begin{array}{l}-0.00562 \\
(0.0116)\end{array}$ & $\begin{array}{l}0.0274 * * * \\
(0.0036)\end{array}$ & $\begin{array}{l}0.0233 * * \\
(0.0111)\end{array}$ \\
\hline Polity2 & $\begin{array}{l}0.00149 * * \\
(0.0006)\end{array}$ & $\begin{array}{l}-0.000629 \\
(0.0005)\end{array}$ & $\begin{array}{l}-0.00106^{*} \\
(0.0006)\end{array}$ & $\begin{array}{l}-0.00506^{* * *} \\
(0.0011)\end{array}$ & $\begin{array}{l}-0.00105 \\
(0.0006)\end{array}$ & $\begin{array}{l}0.00316 \\
(0.0022)\end{array}$ & $\begin{array}{l}0.000549 \\
(0.0003)\end{array}$ & $\begin{array}{l}0.00542 * * * \\
(0.0019)\end{array}$ & $\begin{array}{l}0.00105 \\
(0.0008)\end{array}$ & $\begin{array}{l}-0.00136^{*} \\
(0.0008)\end{array}$ & $\begin{array}{l}0.000508^{* *} \\
(0.0002)\end{array}$ & $\begin{array}{l}-0.00053 \\
(0.0007)\end{array}$ \\
\hline Log(public debt) & $\begin{array}{l}-0.00759^{* * * *} \\
(0.0018)\end{array}$ & $\begin{array}{l}-0.000775 \\
(0.0014)\end{array}$ & $\begin{array}{l}-0.00736^{* * *} \\
(0.0021)\end{array}$ & $\begin{array}{l}-0.00131 \\
(0.0038)\end{array}$ & $\begin{array}{l}-0.00278^{*} \\
(0.0016)\end{array}$ & $\begin{array}{l}0.0188 * * * \\
(0.0057)\end{array}$ & $\begin{array}{l}0.0032 \\
(0.0026)\end{array}$ & $\begin{array}{l}-0.0528 * * * \\
(0.0144)\end{array}$ & $\begin{array}{l}-0.165^{* * *} \\
(0.0334)\end{array}$ & $\begin{array}{l}0.146 * * * \\
(0.0326)\end{array}$ & $\begin{array}{l}-0.00156 \\
(0.0024)\end{array}$ & $\begin{array}{l}0.0123 \\
(0.0075)\end{array}$ \\
\hline Constant & $\begin{array}{l}0.741 * * * \\
(0.0305)\end{array}$ & $\begin{array}{l}0.700 * * * \\
(0.0235)\end{array}$ & $\begin{array}{l}0.967 * * * \\
(0.0181)\end{array}$ & $\begin{array}{l}0.579 * * * \\
(0.0320)\end{array}$ & $\begin{array}{l}0.975 * * * \\
(0.0227)\end{array}$ & $\begin{array}{l}0.261 * * * \\
(0.0784)\end{array}$ & $\begin{array}{l}0.535 * * * \\
(0.0235)\end{array}$ & $\begin{array}{l}1.006 * * * \\
(0.1280)\end{array}$ & $\begin{array}{l}1.274 * * * \\
(0.1170)\end{array}$ & $\begin{array}{l}0.134 \\
(0.1140)\end{array}$ & $\begin{array}{l}0.721 * * * \\
(0.0172)\end{array}$ & $\begin{array}{l}0.511 * * * \\
(0.0533)\end{array}$ \\
\hline Observations & 368 & 368 & 252 & 252 & 190 & 190 & 106 & 106 & 83 & 83 & 158 & 158 \\
\hline R-squared & 0.957 & 0.979 & 0.918 & 0.95 & 0.945 & 0.855 & 0.99 & 0.962 & 0.967 & 0.96 & 0.986 & 0.985 \\
\hline Country-fixed effects & YES & YES & YES & YES & YES & YES & YES & YES & YES & YES & YES & YES \\
\hline Year-fixed effects & YES & YES & YES & YES & YES & YES & YES & YES & YES & YES & YES & YES \\
\hline
\end{tabular}




\section{B. GDI and GII Subcomponents}

Since GDI and GII are each composed of multiple subcomponents, it would be interesting to know which of those subcomponents are the most sensitive to changes in FDI inflows. We use each of the subcomponents as a dependent variable instead of the gender indices.

Table 4 presents results for the subcomponents of GDI. This index measures women's welfare in the following three main dimensions: health (female life expectancy), knowledge (female expected and average years of schooling), and income (gross national income per capita in PPP). We also include two more variables in relative terms to capture the change in GDI subcomponents compared to men: female-to-male life expectancy ratio and female-to-male years of schooling Table 4 shows that the coefficient associated with FDI inflows is positive and strongly significant in all columns. Thus, an increase in FDI inflows is correlated with an increase in female life expectancy, average years of schooling as well as gross national income per capita. As female labor demand increases following inflows of foreign investments, the central government's revenue increases and public investments in infrastructures, such as schools and medical centers, could increase. Additionally, women get empowered as households receive more income. This could lead to a higher absolute and relative share of households' resources allocated to health and education (Schultz, 2005; and Aguayo-Tellez, 2011). 
Table 4. Gender Development Index (GDI) Subcomponents

\begin{tabular}{|c|c|c|c|c|c|c|c|c|c|c|}
\hline & $(1)$ & $(2)$ & (3) & $(4)$ & $(5)$ & $(6)$ & $(7)$ & $(8)$ & $(9)$ & $(10)$ \\
\hline VARIABLES & $\begin{array}{l}\text { Female life } \\
\text { expectancy }\end{array}$ & $\begin{array}{c}\text { Years of } \\
\text { schooling, female }\end{array}$ & $\begin{array}{l}\text { GNI per } \\
\text { capita }\end{array}$ & $\begin{array}{l}\text { Female life } \\
\text { expectancy }\end{array}$ & $\begin{array}{c}\text { Years of } \\
\text { schooling, female }\end{array}$ & GNI per capita & $\begin{array}{l}\text { Female-to- } \\
\text { male life } \\
\text { expectancy }\end{array}$ & $\begin{array}{l}\text { Female-to- } \\
\text { male years } \\
\text { of schooling } \\
\end{array}$ & $\begin{array}{l}\text { Female-to- } \\
\text { male life } \\
\text { expectancy }\end{array}$ & $\begin{array}{l}\text { Female-to- } \\
\text { male years of } \\
\text { schooling }\end{array}$ \\
\hline Log (FDI inflows) & $\begin{array}{l}0.299 * * * \\
(0.0563)\end{array}$ & $\begin{array}{l}0.779 * * * \\
(0.0374)\end{array}$ & $\begin{array}{l}0.341 * * * \\
(0.0108)\end{array}$ & $\begin{array}{l}0.300 * * * \\
(0.0567)\end{array}$ & $\begin{array}{l}0.461 * * * \\
(0.0402)\end{array}$ & $\begin{array}{l}0.214 * * * \\
(0.0113)\end{array}$ & $\begin{array}{l}0.0004 \\
(0.0003)\end{array}$ & $\begin{array}{l}0.0515 * * * \\
(0.0032)\end{array}$ & $\begin{array}{l}0.0005 * \\
(0.0003)\end{array}$ & $\begin{array}{l}0.0331 * * * \\
(0.0037)\end{array}$ \\
\hline GDP growth & $\begin{array}{l}0.222 \\
(0.5300)\end{array}$ & $\begin{array}{l}0.919 \\
(0.6200)\end{array}$ & $\begin{array}{l}-0.281 \\
(0.1790)\end{array}$ & $\begin{array}{l}0.217 \\
(0.5380)\end{array}$ & $\begin{array}{l}1.938 * * * \\
(0.5570)\end{array}$ & $\begin{array}{l}0.0779 \\
(0.1560)\end{array}$ & $\begin{array}{l}0.0072 * * * \\
(0.0022)\end{array}$ & $\begin{array}{l}0.0360 \\
(0.0475)\end{array}$ & $\begin{array}{l}0.0063 * * * \\
(0.0023)\end{array}$ & $\begin{array}{l}0.0795 * \\
(0.0458)\end{array}$ \\
\hline Log(trade openness) & $\begin{array}{l}2.320 * * * \\
(0.2910)\end{array}$ & $\begin{array}{l}0.497 * * * \\
(0.1040)\end{array}$ & $\begin{array}{l}-0.136 * * * \\
(0.0300)\end{array}$ & $\begin{array}{l}2.428 * * * \\
(0.3040)\end{array}$ & $\begin{array}{l}0.628 * * * \\
(0.1000)\end{array}$ & $\begin{array}{l}-0.0135 \\
(0.0281)\end{array}$ & $\begin{array}{l}0.0028 * * \\
(0.0014)\end{array}$ & $\begin{array}{l}0.0690 * * * \\
(0.0101)\end{array}$ & $\begin{array}{l}0.0032 * * \\
(0.0015)\end{array}$ & $\begin{array}{l}0.0801 * * * \\
(0.0108)\end{array}$ \\
\hline Polity2 & $\begin{array}{l}-0.0129 \\
(0.0241)\end{array}$ & $\begin{array}{l}0.0928 * * * \\
(0.0107)\end{array}$ & $\begin{array}{l}0.0244 * * * \\
(0.0031)\end{array}$ & $\begin{array}{l}-0.0121 \\
(0.0248)\end{array}$ & $\begin{array}{l}0.0416^{* * * *} \\
(0.0100)\end{array}$ & $\begin{array}{l}0.00795 * * * \\
(0.0028)\end{array}$ & $\begin{array}{l}-0.00002 \\
(0.0001)\end{array}$ & $\begin{array}{l}0.0079 * * * \\
(0.0009)\end{array}$ & $\begin{array}{l}0.00002 \\
(0.0001)\end{array}$ & $\begin{array}{l}0.0032 * * * \\
(0.0011)\end{array}$ \\
\hline $\log ($ public debt $)$ & $\begin{array}{l}-0.221 * \\
(0.1200)\end{array}$ & $\begin{array}{l}-0.196 * * \\
(0.0855)\end{array}$ & $\begin{array}{l}-0.236 * * * \\
(0.0247)\end{array}$ & $\begin{array}{l}-0.237 * \\
(0.1260)\end{array}$ & $\begin{array}{l}-0.0407 \\
(0.0787)\end{array}$ & $\begin{array}{l}-0.179 * * * \\
(0.0221)\end{array}$ & $\begin{array}{l}-0.0007 \\
(0.0005)\end{array}$ & $\begin{array}{l}-0.0098 \\
(0.0071)\end{array}$ & $\begin{array}{l}-0.0015 * * * \\
(0.0006)\end{array}$ & $\begin{array}{l}-0.0023 \\
(0.0073)\end{array}$ \\
\hline Female population & & & & $\begin{array}{l}0.129 \\
(0.1890)\end{array}$ & $\begin{array}{l}0.0980 * \\
(0.0547)\end{array}$ & $\begin{array}{l}0.0437 * * * \\
(0.0153)\end{array}$ & & & $\begin{array}{l}0.0015^{*} \\
(0.0008)\end{array}$ & $\begin{array}{l}0.0186^{* * * *} \\
(0.0044)\end{array}$ \\
\hline Government expenditures & & & & $\begin{array}{l}-0.0362 * * \\
(0.0149)\end{array}$ & $\begin{array}{l}0.0683^{* * * *} \\
(0.0068)\end{array}$ & $\begin{array}{l}0.00691 * * * \\
(0.0019)\end{array}$ & & & $\begin{array}{l}-0.0002 * * * \\
(0.00007)\end{array}$ & $\begin{array}{l}0.0023 * * * \\
(0.0006)\end{array}$ \\
\hline Natural resources rents & & & & $\begin{array}{l}0.00586 \\
(0.0179)\end{array}$ & $\begin{array}{l}-0.0638^{* * *} \\
(0.0061)\end{array}$ & $\begin{array}{l}-0.0181 * * * \\
(0.0017)\end{array}$ & & & $\begin{array}{l}-0.0001 \\
(0.0001)\end{array}$ & $\begin{array}{l}-0.0035^{* * *} \\
(0.0007)\end{array}$ \\
\hline Rural population & & & & $\begin{array}{l}0.0137 \\
(0.0231)\end{array}$ & $\begin{array}{l}-0.0320^{* * *} \\
(0.0033)\end{array}$ & $\begin{array}{l}-0.0167 * * * \\
(0.0009)\end{array}$ & & & $\begin{array}{l}-0.0003 * * * \\
(0.0001)\end{array}$ & $\begin{array}{l}-0.0019 * * * \\
(0.0003)\end{array}$ \\
\hline Constant & $\begin{array}{l}48.42 * * * \\
(1.7510)\end{array}$ & $\begin{array}{l}3.350 * * * \\
(0.8940)\end{array}$ & $\begin{array}{l}9.193 * * * \\
(0.2580)\end{array}$ & $\begin{array}{l}41.43 * * * \\
(9.4500)\end{array}$ & $\begin{array}{l}-1.588 \\
(2.8570)\end{array}$ & $\begin{array}{l}7.419 * * * \\
(0.8010)\end{array}$ & $\begin{array}{l}1.0780 * * * \\
(0.0070)\end{array}$ & $\begin{array}{l}0.4960 * * * \\
(0.0722)\end{array}$ & $\begin{array}{l}1.0310^{* * *} \\
(0.0400)\end{array}$ & $\begin{array}{l}-0.3810 \\
(0.2370)\end{array}$ \\
\hline Observations & 1,342 & 1,342 & 1,342 & 1,323 & 1,323 & 1,323 & 1,103 & 1,103 & 1,088 & 1,088 \\
\hline R-squared & 0.966 & 0.377 & 0.521 & 0.966 & 0.508 & 0.649 & 0.997 & 0.359 & 0.997 & 0.417 \\
\hline Country-fixed effects & YES & $\mathrm{NO}$ & $\mathrm{NO}$ & YES & $\mathrm{NO}$ & $\mathrm{NO}$ & $\mathrm{NO}$ & NO & $\mathrm{NO}$ & $\mathrm{NO}$ \\
\hline Year-fixed effects & YES & YES & YES & YES & YES & YES & YES & YES & YES & YES \\
\hline
\end{tabular}

Standard errors in parentheses. $* * * \mathrm{p}<0.01$, significant at $1 \% ; * * \mathrm{p}<0.05$, significant at $5 \% ; * \mathrm{p}<0.1$, significant at $10 \%$ 
Similarly, the GII measures gender gaps in the following three main dimensions: reproductive health (maternity mortality ratio), empowerment (percentage of male and female having at least some secondary school years and female share of parliamentary seats), and labor participation (female and male labor participation rates). Table 5 presents the results when we use the subcomponents of the GII as independent variables. It shows that FDI inflows are negatively associated with maternity mortality ratio. Additionally, FDI inflows are positively associated with the female-to-male gross enrolment rate to the secondary level, indicating that female students are catching up to boys in terms of enrolment in secondary schools. Again, as central governments and households have more resources, investments in public facilities make education and healthcare more accessible for girls and women but, households can also allocate more resources to medication and schooling (Kucera, 2001; Schultz, 2005; and Aguayo-Tellez, 2011). Moreover, the coefficient associated with FDI inflows and female-to-male labor participation rate ratio is not significant. This finding is against Aguayo-Tellez and others (2010) and World Bank (2012) who found that FDI could decrease the gender labor participation rate gap or Jaffri and others (2015) who found that FDI could widen the labor participation rate gap. Finally, FDI inflows are surprisingly negatively correlated with the female share of parliamentary seats.

Thus, FDI inflows per capita improve women's welfare and decrease gender disparities by affecting primarily women's health and education. By increasing female labor participation rate and the GNI per capita for females, it is possible that households receive more income that they can allocate to their daughters' education or medication and medical visits. Furthermore, as governments' income increase, part of this extraincome can be invested in building schools and medical centers, improving the access to education for girls and to healthcare. 
Table 5. Gender Inequality Index (GII) Subcomponents

\begin{tabular}{|c|c|c|c|c|c|c|c|c|}
\hline & $(1)$ & $(2)$ & (3) & $(4)$ & $(5)$ & $(6)$ & $(7)$ & $(8)$ \\
\hline VARIABLES & $\begin{array}{l}\text { Maternity } \\
\text { mortality }\end{array}$ & $\begin{array}{l}\text { Gross enrolment } \\
\text { secondary level }\end{array}$ & $\begin{array}{c}\text { Female } \\
\text { parliamentary seats }\end{array}$ & $\begin{array}{c}\text { Female to male } \\
\text { labor participation } \\
\text { rate ratio }\end{array}$ & $\begin{array}{l}\text { Maternity } \\
\text { mortality }\end{array}$ & $\begin{array}{c}\text { Gross enrolment } \\
\text { secondary level }\end{array}$ & $\begin{array}{c}\text { Female } \\
\text { parliamentary seats }\end{array}$ & $\begin{array}{c}\text { Female to male } \\
\text { labor participation } \\
\text { rate ratio } \\
\end{array}$ \\
\hline \multirow[t]{2}{*}{ Log (FDI inflows) } & $-7.063 * * *$ & $0.00874 * * *$ & $-0.271 *$ & -0.0608 & $-7.538 * * *$ & $0.00837 * * *$ & $-0.307 * *$ & -0.00385 \\
\hline & $(1.7080)$ & $(0.00157)$ & $(0.1430)$ & $(0.0903)$ & $(1.6930)$ & $(0.0015)$ & $(0.1420)$ & $(0.0873)$ \\
\hline \multirow[t]{2}{*}{ GDP growth } & 17.01 & 0.0179 & -0.248 & 1.046 & 16.03 & 0.0203 & 0.135 & 0.93 \\
\hline & $(15.6700)$ & $(0.0144)$ & $(1.3110)$ & $(0.8290)$ & $(15.6000)$ & $(0.0142)$ & $(1.3050)$ & $(0.8040)$ \\
\hline \multirow[t]{2}{*}{ Log(trade openness) } & $-55.70 * * *$ & $0.0678 * * *$ & 0.243 & 0.62 & $-57.72 * * *$ & $0.0736 * * *$ & 0.755 & 0.0261 \\
\hline & $(10.3600)$ & $(0.0095)$ & $(0.8660)$ & $(0.5480)$ & $(10.8400)$ & $(0.0099)$ & $(0.9070)$ & $(0.5590)$ \\
\hline \multirow[t]{2}{*}{ Polity2 } & $-2.743 * * *$ & $0.00148^{*}$ & $0.417 * * *$ & $-0.147 * * *$ & $-3.022 * * *$ & $0.00177 * *$ & $0.394 * * *$ & $-0.133 * * *$ \\
\hline & $(0.9120)$ & $(0.0008)$ & $(0.0763)$ & $(0.0482)$ & $(0.9070)$ & $(0.0008)$ & $(0.0759)$ & $(0.0467)$ \\
\hline \multirow[t]{2}{*}{ Log(public debt) } & $27.46 * * *$ & $-0.00953 * *$ & $-0.644^{*}$ & $0.797 * * *$ & $26.23 * * *$ & -0.00498 & $-0.845^{* *}$ & $0.763 * * *$ \\
\hline & $(4.2960)$ & $(0.0039)$ & $(0.3590)$ & $(0.2270)$ & $(4.4760)$ & $(0.0041)$ & $(0.3750)$ & $(0.2310)$ \\
\hline \multirow[t]{2}{*}{ Female population } & & & & & $44.42 * * *$ & $-0.0237 * * *$ & $1.405^{*}$ & 0.643 \\
\hline & & & & & $(9.4810)$ & $(0.0086)$ & $(0.7940)$ & $(0.4890)$ \\
\hline \multirow[t]{2}{*}{ Government expenditures } & & & & & 0.347 & 0.000197 & $0.156 * * *$ & $-0.113 * * *$ \\
\hline & & & & & $(0.4600)$ & $(0.0004)$ & $(0.0385)$ & $(0.0237)$ \\
\hline \multirow[t]{2}{*}{ Natural resources rents } & & & & & -0.4 & $-3.27 \mathrm{E}-07$ & $-0.137 * * *$ & $0.0705 * *$ \\
\hline & & & & & $(0.5340)$ & $(0.0005)$ & $(0.0447)$ & $(0.0275)$ \\
\hline \multirow[t]{2}{*}{ Rural population } & & & & & $2.389 * *$ & -0.00133 & 0.0758 & $-0.144 * * *$ \\
\hline & & & & & $(0.9330)$ & $(0.0008)$ & $(0.0781)$ & $(0.0481)$ \\
\hline \multirow[t]{2}{*}{ Constant } & $639.6 * * *$ & $0.264 * * *$ & $17.02 * * *$ & $9.320 * * *$ & $-1,704 * * *$ & $1.493 * * *$ & -62.49 & -5.434 \\
\hline & $(59.3300)$ & $(0.0544)$ & $(4.9620)$ & $(3.1380)$ & $(474.7000)$ & $(0.4340)$ & $(39.7300)$ & $(24.4600)$ \\
\hline Observations & 915 & 915 & 915 & 915 & 908 & 908 & 908 & 908 \\
\hline R-squared & 0.977 & 0.949 & 0.874 & 0.984 & 0.978 & 0.95 & 0.877 & 0.985 \\
\hline Country-fixed effects & YES & YES & YES & YES & YES & YES & YES & YES \\
\hline Year-fixed effects & YES & YES & YES & YES & YES & YES & YES & YES \\
\hline
\end{tabular}




\section{Other Employment Variables}

In this section, we investigate the impact of FDI inflows on other type of gender related-labor variables beyond the gender development and inequality indices. Given that the gender development and inequality indices used so far do not cover all gender related labor indicators, it appears interesting to analyze whether FDI inflows impact other type of labor variables that have been used in previous literature. This could give us more insight about which dimensions of female employment are affected by foreign investments. To do so, we selected the following set of employment indicators (summary statistics and data sources are available in annex):

- Female to male ratio of employers (in percentage of employment),

- Female informal employment in percentage of total employment (25 years average),

- Female to male ratio of part-time employment as a percentage of total employment (25 years average),

- Gender wage gap (25 years average).

Results reported in Table 6 signal that FDI inflows could improve female employment (see columns 2, 3, 5, and 6). First, FDI inflows are negatively correlated with female informal employment in percentage of total employment. Multinationals and other majority-foreign owned firms increase female labor demand when they create or invest in firms in host countries. New employment opportunities and higher wages in those firms (Kucera, 2001; Olcott and Oliver, 2014; and Abe, Javorcik, and Kodama, 2016) entice women workers to transfer from the informal to the formal sector.

Second, we find that FDI inflows are negatively associated with the female-to-male part-time employment ratio in percentage of total employment. It could be that the extra female labor demand by multinationals or majority-owned foreign firms is offered in full-time positions, thus decreasing female part-time employment while leaving male part-time employment unchanged. Determining whether the change in this ratio is Pareto efficient and whether FDI inflows don't hurt male employment is out of this paper's scope and left for further research.

Finally, it appears that FDI inflows are negatively correlated with the gender wage gap (columns 4 and 8). Again, as described in Section II, foreign participation is associated with higher wage than domestic similar firms. Furthermore, as local suppliers or consumers have to adapt to new technology, they will have to train their workers and potentially offer a wage premium to avoid the workers going to another firm. If FDI inflows are receiving in low skilled, labor intensive sectors that rely predominantly on female workforce, then foreign investments can indeed decrease the gender wage gap (Kucera, 2001; Olcott and Oliver, 2014; and Abe, Javorcik, and Kodama, 2016). Our finding is contrary to Rasekhi and Hosseinmardi (2012) and Vijaya and Kaltani (2007) who highlighted that some firms only 
seek to benefit from female workers' lower wages. Rasekhi and Hosseinmardi (2012) found that FDI inflows in manufacturing had a negative impact on female workers' wages in a panel of 19 countries.

Table 6. Using Other Gender Related Employment Variables

\begin{tabular}{|c|c|c|c|c|c|c|c|c|}
\hline & (1) & (2) & (3) & (4) & (5) & (6) & (7) & (8) \\
\hline VARIABLES & $\begin{array}{l}\text { Female to Male } \\
\text { employers ratio }\end{array}$ & $\begin{array}{c}\text { Female informal } \\
\text { employment }\end{array}$ & $\begin{array}{l}\text { Female to male part- } \\
\text { time employment ratio }\end{array}$ & $\begin{array}{c}\text { Gender } \\
\text { wage gap }\end{array}$ & $\begin{array}{l}\text { Female to Male } \\
\text { employers ratio }\end{array}$ & $\begin{array}{c}\text { Female informal } \\
\text { employment }\end{array}$ & $\begin{array}{l}\text { Female to male part- } \\
\text { time employment ratio }\end{array}$ & $\begin{array}{r}\text { Gender } \\
\text { wage gap }\end{array}$ \\
\hline Log(FDI inflows) & $\begin{array}{l}0.0103 \\
(0.0099)\end{array}$ & $\begin{array}{l}-5.137^{* * *} \\
(1.0850)\end{array}$ & $\begin{array}{l}-0.0974 * * \\
(0.0485)\end{array}$ & $\begin{array}{l}-2.974 * * * \\
(0.4560)\end{array}$ & $\begin{array}{l}0.0122 \\
(0.0101)\end{array}$ & $\begin{array}{l}-3.962 * * * \\
(0.9300)\end{array}$ & $\begin{array}{l}-0.0913^{*} \\
(0.0536)\end{array}$ & $\begin{array}{l}-2.589^{* * *} \\
(0.5010)\end{array}$ \\
\hline GDP growth & $\begin{array}{l}0.113^{*} \\
(0.0684)\end{array}$ & $\begin{array}{l}0.801 \\
(12.1000)\end{array}$ & $\begin{array}{l}-0.355 \\
(0.5410)\end{array}$ & $\begin{array}{l}0.894 \\
(5.0890)\end{array}$ & $\begin{array}{l}0.120^{*} \\
(0.0689)\end{array}$ & $\begin{array}{l}-5.371 \\
(8.7830)\end{array}$ & $\begin{array}{l}-0.315 \\
(0.5060)\end{array}$ & $\begin{array}{l}0.538 \\
(4.7300)\end{array}$ \\
\hline Log(trade openness) & $\begin{array}{l}0.0968^{*} \\
(0.0538)\end{array}$ & $\begin{array}{l}-12.83^{* * *} \\
(2.3200)\end{array}$ & $\begin{array}{l}-0.872 * * * \\
(0.1040)\end{array}$ & $\begin{array}{l}-9.181 * * * \\
(0.9760)\end{array}$ & $\begin{array}{l}0.115^{* *} \\
(0.0580)\end{array}$ & $\begin{array}{l}-11.75^{* * *} \\
(2.0980)\end{array}$ & $\begin{array}{l}-1.035^{* * *} \\
(0.1210)\end{array}$ & $\begin{array}{l}-11.64 * * * \\
(1.1300)\end{array}$ \\
\hline Polity2 & $\begin{array}{l}0.00171 \\
(0.0031)\end{array}$ & $\begin{array}{l}-0.494 \\
(0.4050)\end{array}$ & $\begin{array}{l}-0.0790^{* * *} \\
(0.0181)\end{array}$ & $\begin{array}{l}-0.229 \\
(0.1700)\end{array}$ & $\begin{array}{l}0.00237 \\
(0.0031)\end{array}$ & $\begin{array}{l}-0.345 \\
(0.3250)\end{array}$ & $\begin{array}{l}-0.0478^{* *} \\
(0.0187)\end{array}$ & $\begin{array}{l}-0.0352 \\
(0.1750)\end{array}$ \\
\hline Log(public debt) & $\begin{array}{l}-0.0499 * * \\
(0.0221)\end{array}$ & $\begin{array}{l}1.179 \\
(2.1150)\end{array}$ & $\begin{array}{l}-0.143 \\
(0.0945)\end{array}$ & $\begin{array}{l}2.072 * * \\
(0.8890)\end{array}$ & $\begin{array}{l}-0.0462^{* *} \\
(0.0233)\end{array}$ & $\begin{array}{l}2.909^{*} \\
(1.5510)\end{array}$ & $\begin{array}{l}-0.164^{*} \\
(0.0893)\end{array}$ & $\begin{array}{l}2.471 * * * \\
(0.8350)\end{array}$ \\
\hline Female population & & & & & $\begin{array}{l}0.0332 \\
(0.0307)\end{array}$ & $\begin{array}{l}0.859 \\
(0.9620)\end{array}$ & $\begin{array}{l}-0.326^{* * *} \\
(0.0554)\end{array}$ & $\begin{array}{l}-1.590^{* * *} \\
(0.5180)\end{array}$ \\
\hline Government expenditures & & & & & $\begin{array}{l}-9.95 \mathrm{E}-05 \\
(0.0028)\end{array}$ & $\begin{array}{l}-1.815^{* * *} \\
(0.1190)\end{array}$ & $\begin{array}{l}0.0172^{* *} \\
(0.0068)\end{array}$ & $\begin{array}{l}-0.0988 \\
(0.0638)\end{array}$ \\
\hline Natural resources rents & & & & & $\begin{array}{l}-0.00990^{* *} \\
(0.0041)\end{array}$ & $\begin{array}{l}0.618^{* * *} \\
(0.2350)\end{array}$ & $\begin{array}{l}-0.0282 * * \\
(0.0135)\end{array}$ & $\begin{array}{l}-0.463^{* * *} \\
(0.1260)\end{array}$ \\
\hline Rural population & & & & & $\begin{array}{l}0.00447 \\
(0.0032)\end{array}$ & $\begin{array}{l}-0.113 \\
(0.0823)\end{array}$ & $\begin{array}{l}0.00816^{*} \\
(0.0047)\end{array}$ & $\begin{array}{l}0.0697 \\
(0.0444)\end{array}$ \\
\hline Constant & $\begin{array}{l}-0.0531 \\
(0.2520)\end{array}$ & $\begin{array}{l}137.7^{* * *} \\
(18.8900)\end{array}$ & $\begin{array}{l}7.649 * * * \\
(0.8440)\end{array}$ & $\begin{array}{l}55.13 * * * \\
(7.9410)\end{array}$ & $\begin{array}{l}-1.963 \\
(1.4760)\end{array}$ & $\begin{array}{l}121.0^{* *} \\
(49.2900)\end{array}$ & $\begin{array}{l}23.77 * * * \\
(2.8390)\end{array}$ & $\begin{array}{l}141.2 * * * \\
(26.5500)\end{array}$ \\
\hline Observations & 284 & 284 & 284 & 284 & 284 & 284 & 284 & 284 \\
\hline R-squared & 0.597 & 0.296 & 0.37 & 0.443 & 0.609 & 0.63 & 0.45 & 0.52 \\
\hline Country-fixed effects & YES & NO & NO & NO & YES & NO & NO & NO \\
\hline Year fixed effects & YES & YES & YES & YES & YES & YES & YES & YES \\
\hline
\end{tabular}

\section{FDI Inflows And Gender Policies}

We have found that FDI inflows are positively associated with gender development (GDI) and negatively associated with gender inequality (GII). Thus, FDI inflows help improve women's welfare and decrease gender disparities, mostly in health and education.

Concerning employment, FDI inflows help women achieve greater integration into the formal labor market by decreasing female informal employment, decreasing the gap between women and men in part-time employment and decreasing the gender wage. However, one question remains: do those results differ according to recipient countries' characteristics? Can host countries' governments enhance the effect of FDI on gender development and inequality by implementing some specific policies? We selected three highly debated gender policies implemented by some countries in our sample to assess whether they influence the impact of FDI inflows on GDI and GII. To this end, we created a dummy variable for each of those three policies and interacting them with the FDI inflows variable: 
- Gender budgeting: dummy equal to 1 if the country has some gender budgeting programs in place. Gender budgeting uses fiscal policy and administration to promote gender equality and female's development.

- Law mandating equal remuneration between women and men: dummy equal to 1 if the country has a law mandating equal wage.

- Law mandating non-discrimination in hiring: dummy equal to 1 if the country has a law mandating non-discrimination.

- In addition, we use a female access to resources index from the OECD (Gender, Institutions, and Development) ranging from 0 to 1 , with 0 meaning there is no discrimination against women. This index assesses whether there is equal access to land (use, control, and ownership) between women and men, equal access to non-land assets, and equal access to financial services.

- Finally, we used the number of procedures to register a business for women and men to create a dummy equal to 1 if women face a higher number of procedures. The number of procedures to register a business indicator was taken from the World Bank - Doing Business database and it shows the number of procedures required to start a business such as the steps to obtain the necessary permits and licences.

Our results presented in Table 7 indicate that the interactive coefficient between the gender budgeting and FDI inflows is not statistically significant (columns 1 and 2). The nonsignificance of the interaction variable's coefficients implies that the impact of FDI inflows on women's welfare and gender disparities is independent of the implementation of a gender budgeting program. Hence, while gender budgeting programs promise to reduce gender disparities as long as those programs are built around sound budgeting principles and practices (Stotsky, 2016), our paper fails to find that gender budgeting enhances the impact of FDI on gender development and inequality. The fact that gender budgeting is still a recent topic and not well developed in developing countries might explain this lack of significance.

We also find that the interactive coefficients between laws mandating equal remuneration and non-discrimination in hiring and FDI inflows is not statistically significant. The effect of FDI inflows on GDI and GII is independent of those two policies. Previous results had indicated that some firms could take advantage of the gender wage gap to hire the low-cost female labor (Rasekhi and Hosseinmardi, 2012), but also that, on contrary, wage discrimination could penalize firms seeking to compete in the labor market (Becker, 1957). Those two opposite trends could explain why the coefficients of the interaction variable for equal wage and non-discrimination are not significant.

Table 7 shows that the interactive coefficient between FDI inflows and low female access to resources is statistically significant and positive (column 8). That said, the net marginal effect 
of FDI on gender inequality in countries with low female access to resources is positive. Hence, in a country where women do not have access to land, non-land assets, or financial resources, FDI inflows could increase gender disparities. This result stems from the fact that access to resources is linked to decision making in a household. If a woman needs to ask permission to her husband to open a bank account or cannot own assets in her own name, it could be also the case that she needs his permission to work. Thus, men will benefit the most from FDI inflows by working for those MNEs or majority-foreign owned firms and bringing in income in the households. This could even worsen women's bargaining power within the household.

Finally, we find that the interactive coefficient between FDI and the dummy indicator for higher number of procedures to open a business for women is negative and statistically significant in column (9). Thus, the impact of FDI on gender development is dampened in countries where women face higher number of procedures to open a business compared to men. In other words, the poorer the business environment for women, the lower the impact of FDI on gender development. Furthermore, Table 7 shows the interactive coefficient between FDI and the number of procedures to open a business for women is positive and statistically significant in column (10) and the total net coefficient is positive. That said, FDI may increase gender inequality in countries with significant burden for women to open a business. Indeed, facing a huge hardship could discourage women to take business initiatives and thus they miss the opportunities from foreign investors and associated spillover effects. 
Table 7. FDI Inflows and Gender Policies

\begin{tabular}{|c|c|c|c|c|c|c|c|c|c|c|}
\hline & $(1)$ & $(2)$ & $(3)$ & $(4)$ & $(5)$ & $(6)$ & $(7)$ & $(8)$ & (9) & $(10)$ \\
\hline & (GDI) & (GII) & (GDI) & (GII) & (GDI) & (GII) & (GDI) & (GII) & (GDI) & (GII) \\
\hline $\log (\mathrm{FDI}$ inflows $)$ & $\begin{array}{l}0.00389 * * * \\
(0.0006)\end{array}$ & $\begin{array}{l}-0.00266^{* * *} \\
(0.0009)\end{array}$ & $\begin{array}{l}0.00230^{* * *} \\
(0.0007)\end{array}$ & $\begin{array}{l}-0.00108 \\
(0.0012)\end{array}$ & $\begin{array}{l}0.00312 * * * \\
(0.0006)\end{array}$ & $\begin{array}{l}-0.00209^{*} \\
(0.0012)\end{array}$ & $\begin{array}{l}0.00555^{* * *} \\
(0.0016)\end{array}$ & $\begin{array}{l}-0.00813 * * * \\
(0.0027)\end{array}$ & $\begin{array}{l}0.0030^{* * *} \\
(0.0006)\end{array}$ & $\begin{array}{l}-0.0019 * \\
(0.0011)\end{array}$ \\
\hline Log(FDI inflows)*Gender budgeting & $\begin{array}{l}-0.0004 \\
(0.0004)\end{array}$ & $\begin{array}{l}0.000517 \\
(0.0006)\end{array}$ & & & & & & & & \\
\hline $\log ($ FDI inflows)*Equal wage & & & $\begin{array}{l}-0.00158 \\
(0.0015)\end{array}$ & $\begin{array}{l}0.00429 \\
(0.0027)\end{array}$ & & & & & & \\
\hline $\log (\mathrm{FDI} \text { inflows })^{*}$ Non discrimination & & & & & $\begin{array}{l}-0.000729 \\
(0.0008)\end{array}$ & $\begin{array}{l}0.00113 \\
(0.0014)\end{array}$ & & & & \\
\hline $\begin{array}{l}\log (\mathrm{FDI} \text { inflows })^{*} \text { Low access to } \\
\text { resources }\end{array}$ & & & & & & & $\begin{array}{l}-0.00377 \\
(0.0029)\end{array}$ & $\begin{array}{l}0.0104 * * \\
(0.0051)\end{array}$ & & \\
\hline $\begin{array}{l}\log (F D I \text { inflows })^{*} \text { number of } \\
\text { procedures to open a business }\end{array}$ & & & & & & & & & $\begin{array}{l}-0.0019 * * \\
(0.0009)\end{array}$ & $\begin{array}{l}0.0041 * * \\
(0.0018)\end{array}$ \\
\hline GDP growth & $\begin{array}{l}0.00406 \\
(0.0050)\end{array}$ & $\begin{array}{l}0.0164^{*} \\
(0.0089)\end{array}$ & $\begin{array}{l}0.00416 \\
(0.0066)\end{array}$ & $\begin{array}{l}0.0147 \\
(0.0121)\end{array}$ & $\begin{array}{l}-0.00382 \\
(0.0063)\end{array}$ & $\begin{array}{l}0.0253 * * \\
(0.0111)\end{array}$ & $\begin{array}{l}0.00322 \\
(0.0059)\end{array}$ & $\begin{array}{l}0.0188^{*} \\
(0.0105)\end{array}$ & $\begin{array}{l}0.0049 \\
(0.0049)\end{array}$ & $\begin{array}{l}0.0103 \\
(0.0096)\end{array}$ \\
\hline Log(trade openness) & $\begin{array}{l}0.00840 * * * \\
(0.0029)\end{array}$ & $\begin{array}{l}0.00222 \\
(0.0053)\end{array}$ & $\begin{array}{l}0.00815^{* *} \\
(0.0037)\end{array}$ & $\begin{array}{l}0.00353 \\
(0.0068)\end{array}$ & $\begin{array}{l}0.00597 \\
(0.0038)\end{array}$ & $\begin{array}{l}-0.00897 \\
(0.0066)\end{array}$ & $\begin{array}{l}0.0132 * * * \\
(0.0033)\end{array}$ & $\begin{array}{l}0.00711 \\
(0.0057)\end{array}$ & $\begin{array}{l}0.0063^{* *} \\
(0.0030)\end{array}$ & $\begin{array}{l}0.0027 \\
(0.0059)\end{array}$ \\
\hline Polity2 & $\begin{array}{l}0.000988 * * * \\
(0.0003)\end{array}$ & $\begin{array}{l}-0.000780^{*} \\
(0.0005)\end{array}$ & $\begin{array}{l}0.00124 * * * \\
(0.0003)\end{array}$ & $\begin{array}{l}-0.000386 \\
(0.0006)\end{array}$ & $\begin{array}{l}0.00104 * * * \\
(0.0003)\end{array}$ & $\begin{array}{l}0.00016 \\
(0.0005)\end{array}$ & $\begin{array}{l}0.00104^{* * *} \\
(0.0003)\end{array}$ & $\begin{array}{l}-0.00061 \\
(0.0005)\end{array}$ & $\begin{array}{l}0.0009 * * * \\
(0.0002)\end{array}$ & $\begin{array}{l}-0.0018^{* * *} \\
(0.0005)\end{array}$ \\
\hline Log(public debt) & $\begin{array}{l}-0.00521 * * * \\
(0.0011)\end{array}$ & $\begin{array}{l}0.00476^{* *} \\
(0.0020)\end{array}$ & $\begin{array}{l}-0.00504^{* * *} \\
(0.0014)\end{array}$ & $\begin{array}{l}0.00305 \\
(0.0025)\end{array}$ & $\begin{array}{l}-0.00464 * * * \\
(0.0013)\end{array}$ & $\begin{array}{l}-0.000726 \\
(0.0023)\end{array}$ & $\begin{array}{l}-0.00622 * * * \\
(0.0014)\end{array}$ & $\begin{array}{l}0.00259 \\
(0.0024)\end{array}$ & $\begin{array}{l}-0.0061 * * * \\
(0.0012)\end{array}$ & $\begin{array}{l}-0.0059 * * \\
(0.0024)\end{array}$ \\
\hline Constant & $\begin{array}{l}0.586^{* * * *} \\
(0.0157)\end{array}$ & $\begin{array}{l}0.654 * * * \\
(0.0279)\end{array}$ & $\begin{array}{l}0.588 * * * \\
(0.0181)\end{array}$ & $\begin{array}{l}0.651 * * * \\
(0.0331)\end{array}$ & $\begin{array}{l}0.595 * * * \\
(0.0181)\end{array}$ & $\begin{array}{l}0.712 * * * \\
(0.0315)\end{array}$ & $\begin{array}{l}0.570 * * * \\
(0.0167)\end{array}$ & $\begin{array}{l}0.640 * * * \\
(0.0291)\end{array}$ & $\begin{array}{l}0.5690 * * * \\
(0.0142)\end{array}$ & $\begin{array}{l}0.7410 * * * \\
(0.0277)\end{array}$ \\
\hline Observations & 1,157 & 1,157 & 742 & 742 & 858 & 858 & 950 & 950 & 839 & 839 \\
\hline R-squared & 0.969 & 0.962 & 0.969 & 0.962 & 0.966 & 0.961 & 0.967 & 0.959 & 0.98 & 0.974 \\
\hline Country-fixed effects & YES & YES & YES & YES & YES & YES & YES & YES & YES & YES \\
\hline Year-fixed effects & YES & YES & YES & YES & YES & YES & YES & YES & YES & YES \\
\hline
\end{tabular}

Standard errors in parentheses. $* * * \mathrm{p}<0.01$, significant at $1 \%$; $* * \mathrm{p}<0.05$, significant at $5 \%$; ${ }^{*} \mathrm{p}<0.1$, significant at $10 \%$ 


\section{Robustness Tests}

In this section, we test the robustness of our results by undertaking the following regressions.

Our first robustness test is to use alternate data sources for FDI. Instead of IMF's Statistics department's dataset, we use FDI inflows data from the United Nations' datasets and the IMF's World Economic Outlook to check for potential differences between different datasets. Our results, presented in Table 8 in Appendix III, are nearly identical to our baseline Table 1. FDI inflows is positively associated with gender development and negatively associated with gender inequality as shown in Table 1.

The second robustness test is to instrument for FDI inflows. According to the literature, manufacturing firms under intense cost pressure and competition could seek to implement plants in countries with a high gender wage gap to take advantage of the low wages of female workers. Furthermore, as explained in Kazandjian and others (2016), gender inequality negatively impacts exports diversification by limiting the potential pool of human capital available and decreasing the workforce efficiency. Thus, to tackle the potential double causality issue, we instrument FDI with the U.S. equity-market uncertainty index as done in Ouedraogo (2017). We expect this instrument to be valid as it should be correlated with the inflows of FDI in recipient countries but not with gender inequality or development. This estimation, whose results are presented in Table 9 in Appendix IV, also gives similar results. FDI inflows is positively correlated with the GDI and is negatively associated with the GII.

Third, we include additional variables to control for the potential role of domestic norms and social culture. As described in Section II, religion has an important role to play in gender development and inequality (Cooray and Potrafke, 2011). We control for the index of ethnic fractionalization, and the percentage of various religious groups in the recipient countries, including Islam, Catholicism, Protestantism, Hinduism, and Buddhism. The results are reported in Table 10. We observe that even controlling for the role of religion and ethnic diversity, our main findings remain intact. Moreover, we find that the higher the share of Muslims and Hinduists, the lower the level of gender development and the higher the level of gender inequality. In addition, the shares of Catholics and Protestants are positively associated with gender development and gender inequality.

Fourth, in our third robustness test, we use FDI inflows in percentage of GDP instead of FDI inflows per capita as it is the indicator used in some studies (Neumayer and de Soysa, 2010; Goel, 2016; and Anyanwu, 2016). Table 11 in Appendix VI shows that the results are consistent with those of Table 1. FDI inflows in percentage of GDP is positively associated with gender development and negatively associated with gender disparities.

Finally, we use alternative dependant variables constructed by Stotsky and others (2016). The indices by Stotsky and others (2016) are similar to those of UNDP, but they extend UNDP data backward in time to take on board the change in methodologies and computations made 
by UNDP in 2014. The results reported in Table 12 in Appendix VII are in line with our baseline findings in Table 1.

\section{CONCLUSIONS}

In summary, this paper shows that FDI inflows are positively associated with gender development and negatively correlated with gender inequality. Hence, FDI inflows help improve women's welfare and decrease gender disparities mostly in health and education. In fact, we found that out of the three different dimensions of gender development (health, education, and income) and of gender inequality (reproductive health, empowerment in politics and education, and labor participation), FDI inflows are positively associated with female life expectancy and negatively correlated with maternal mortality ratio, as well as female-to-male gross enrolment rate in secondary schools. As households' and government's revenue increase through the presence of MNEs and majority-foreign owned firms, parents can invest more in girls' education and access to schools becomes less restricted. Similarly, an increase in households' and government's income means that workers will have more resources to allocate to medication and medical visits, and will have access to closer medical centers. Moreover, our findings show that foreign investments are negatively associated with gender wage gap, female informal employment as well as the gap in part-time employment rate between women and men. It appears that FDI inflows are bringing women in the formal sector and helping them to be better and more fully integrated to the labor market.

However, the paper finds that the impact of FDI on gender development and inequality differs across geographic regions and income groups. FDI inflows seem to have a stronger positive impact on gender development in Sub-Saharan Africa, Latin America and Caribbean, Middle East and North Africa, and East Asia and Pacific. We find that FDI is negatively associated with gender development in South East Asia, probably because this region receives a lot of investments in technological sectors which rely predominantly on a skilled, male, labor workforce. Furthermore, the results show that FDI is strongly and negatively correlated with gender disparities in Europe and Central Asia, Middle East and North Africa, and East Asia and Pacific. Regarding the income groups, we find that the impact of FDI on gender development is stronger for middle income countries than for low income countries. This is explained by the fact that low income countries receive a large share of FDI in the primary sector, which rely on human physical capital. Hence in low income countries, male labor demand may increase more than female labor demand.

In terms of policy implications, the findings suggest that FDI inflows and the private sector in general can help central governments achieve greater gender development and equality through increased female labor demand or sustainable labor practices and gender equal norms via the CSR initiatives. It is then important to promote foreign investments in developing countries, but also to encourage the creation of CSR initiatives in the workplace. Another important finding is that developing countries should ease women's access to resources in order to fully benefit from FDI. Policy makers should not only make sure that 
women are free to seize the economic and labor opportunities generated by MNEs and majority-foreign owned firms but also that they have unrestricted access to the resulting income. Finally, developing countries should improve the business environment for women by simplifying and shortening all the paperwork that women face to open a business.

We recognize that this study would benefit from taking into account the economic sectors the investment flows in. A sectoral analysis would however require more detailed data than what is currently available so we leave this work for future research. 


\section{REFERENCES}

Abe, Y., B. Javorcik, and N. Kodama, 2016, Transplanting Corporate Culture across International Borders: FDI and female employment in Japan, RIETI Discussion Paper Series, 16-E-015.

Acemoglu, D., 1998, Why Do New Technologies Complement Skills? Directed Technical Change and Wage Inequality, The Quarterly Journal of Economics, Vol. 113, No. 4, pp. 1055-1089.

Aguayo-Tellez, E., and Airola, J. and Juhn, C., 2010, Did Trade Liberalization Help Women? The Case of Mexico in the 1990s, National Bureau of Economic Research, Inc, NBER Working Papers: 16195.

Aguayo-Tellez, E., 2011, The Impact of Trade Liberalization Policies and FDI on Gender Inequalities, a Literature Review, World Development Report 2012, Gender Equality and Development, Background paper.

Alfaro.L, Kalemli-Ozcan.S, and V. Volosovych, 2008, Why doesn't Capital Flow from Rich to Poor Countries? An Empirical Investigation, Review of Economics and Statistics, May, 90(2): pp. 347-368.

Anyanwu, J. C., 2016, “Analysis of Gender Equality in Youth Employment in Africa," African Development Review, Vol. 28, No. 4, pp. 397-415.

Becker, G.S., 1971, “The economics of discrimination," University of Chicago Press, second edition.

Björkman Nyqvist, M., and S. Jayachandran, 2017, "Mothers Care More, but Fathers Decide: Educating Parents about Child Health in Uganda," American Economic Review, 107(5): pp. 496-500.

Braunstein, E., 2006, "Foreign Direct Investment, Development and Gender Equity: A Review of Research and Policy," United Nations Research Institute for Social Development, occasional paper.

Carr, S. P., 2016, "Investing in Equality: A Case for Motivating Gender Empowerment Through Foreign Direct Investment," Georgetown University, Graduate School of Arts and Science, thesis.

Castilla, C., and T. Walker, 2013, "Is Ignorance Bliss? The Effect of Asymmetric Information between Spouses on Intra-Household Allocations," American Economic Review, Vol. 103, No. 3, pp. 263-68. 
Chen, D. H. C., 2004, "Gender Equality and Economic Development: The Role for Information and Communication Technologies," World Bank Policy Research Working Paper 3285, Washington DC

Chen, J., 2006, "Migration and Imperfect Monitoring: Implications for Intra-Household Allocation," American Economic Review, Vol. 96, No. 2, pp. 227-231.

Chen, Z., Y. Ge, H. Lai, and C. Wan, 2013, "Globalization and Gender Wage Inequality in China," World Development, Vol. 44, pp. 256-266.

Cooray, A., and N. Potrafke, 2011, "Gender Inequality in Education: Political Institutions or Culture and Religion?", European Journal of Political Economy, Vol. 27, pp. 268-280.

Crespo, N., and M. P. Fontoura, 2007, "Determinant Factors of FDI Spillovers - What Do We Really Know?”, World Development, Vol. 35, No. 3, pp. 410-425.

Davin, D., 2004, "The Impact of Export-oriented Manufacturing on the Welfare Entitlements of Chinese Women Workers," Globalization, Export-oriented Employment and Social Policy, pp. 67-90.

Dieterich, C., Huang, A., and Thomas, A., 2016, Women's opportunities and challenges in sub-Saharan African job markets, IMF Working Paper Series WP/16/118, Washington DC, USA.

Fussell, E., 2000, "Making Labor Flexible: The Recomposition of Tijuana's Maquiladora Female Labor Force," Feminist Economics, Vol. 6, No.3, pp. 59-79.

Glass, A. J., and K. Saggi, 2002, "Multinational Firms and Technology Transfer," Scand. Journal of Economics, Vol. 104, No. 4, pp. 495-513.

Goel, R. K., 2016, "Foreign Direct Investment and Entrepreneurship: Gender Differences Across the World," Asian Development Bank, Conference on Foreign Direct Investment, June 2016.

Jacob, J. and S. Sasso, 2016, "Foreign direct investment and technology spillovers in low and middle-income countries: A comparative cross-sectoral analysis," UNIDO, Industrial Development Report 2016: IDR 2016 WP 5.

Jaffri, A. A., M. Sana, and R. Asjed, 2015, "Impact of Globalization on Gender Inequality in Labour Market of Pakistan”. Pakistan Economic and Social Review, Vol. 53, No. 1, pp. 1-16.

Javorcik, B. S., 2004, "Does Foreign Direct Investment Increase the Productivity of Domestic Firms? In Search of Spillovers Through Backward Linkages," American Economic Review, Vol. 94, No. 3, pp. 605-627. 
Jonsson, L., 2015, "Is There an Impact of Foreign Direct Investments on Gender Equality? A Study of Female Employment in Latin America and the Caribbean," Lund University, Department of Economics, thesis.

Juhn, C., G. Ujhelyi, and C. Villegas-Sanchez, 2013, "Trade Liberalization and Gender Inequality," American Economic Review, Vol. 103, No. 3, pp. 269-273.

Kazandjian, R., L. Kolovich, K. Kochhar, and M. Newiak, 2016, "Gender Equality and Economic Diversification," IMF Working Paper 16/140, Washington: International Monetary Fund

Kochhar, K., S. Jain-Chandra, and M. Newiak, 2016, Women, Work, and Economic Growth: Leveling the Playing Field, eds 2016. International Monetary Fund, Washington, DC.

Kucera, D., 2001, “The Effects of Core Workers Rights on Labour Costs and Foreign Direct Investment: Evaluating the "Conventional Wisdom"," International Institute for Labour Studies Discussion Paper 130, ILO, Geneva.

Kwok, C. CY., and S. Tadesse, 2006, "The MNC as an Agent of Change for Host-Country Institutions: FDI and Corruption”. Journal of International Business Studies, Vol. 37, pp. 767-785.

Nelson, J., M. Porth, K. Valikai, and H. McGee, 2015, “A Path to Empowerment: The Role of Corporations in Supporting Women's Economic Progress," Corporate Social Responsibility Initiative at the Harvard Kennedy School and the U.S. Chamber of Commerce Foundation Corporate Citizenship Center.

Neumayer, E., and I. de Soysa, 2011, "Globalization and the empowerment of women: an analysis of spatial dependence via trade and foreign direct investment," World Development, Vol. 39, No. 7, pp. 1065-1074.

OECD, 2001, "Corporate Responsibility: Results of a Fact-Finding Mission on Private Initiatives”, OECD Working Papers on International Investment, 2001/02, OECD Publishing.

Olcott, G., and N. Oliver, 2014, “The impact of foreign ownership on gender and employment relations in large Japanese companies". Work, employment and society, Vol. 28, issue 2, pp. 206-224.

Ouedraogo, R., 2017, "Portfolio Inflows and Real Effective Exchange Rates: Does the Sectorization Matter?" International Monetary Fund (IMF), Working Paper WP/17/121.

Rasekhi, S. and H. Hosseinmardi, 2012, “An Impact of Globalization on Gender Wage Inequality: A Case Study of Selected Developing Countries," International Journal of Business and Development Studies, Vol. 4, No. 1, pp. 27-40. 
Rodrik, D., 1997, "Trade Strategy, Exports, and Investment: Another Look at East Asia," Pacific Economic Review, Vol. 2, No. 1, pp. 1-24.

Schultz, T. P., 2005, "Does the Liberalization of Trade Advance Gender Equality in Schooling and Health?", Economic Growth Center, Yale University, Discussion Papers No. 935.

Seguino, S., and C. Grown, 2006, "Gender Equity and Globalization: Macroeconomics Policy for Developing Countries," Journal of International Development, Vol. 18, pp. 1081-1104.

Stotsky, J. G., 2016, "Gender Budgeting: Fiscal Context and Current Outcomes," International Monetary Fund (IMF), Working Paper No. 16/149.

Stotsky, J.G., Shibuya, S., Kolovich, L., and Kebhaj, S., 2016, Trends in gender equality and women's advancement, IMF Working Paper Series WP/16/21. Washington DC, USA

Tang, H., and Y. Zhang, 2014, "Cross-Country Diffusion of Culture through FDI: A FirmLevel Analysis of Gender Inequality in China", Working Paper.

Tejani, S., and W. Milberg, 2010, “Global Defeminization: Industrial Upgrading, Occupational Segmentation and Manufacturing Employment in Middle-Income Countries," SCEPA Working Papers.

UNCTAD, 2014, Investment by TNCs and Gender: Preliminary Assessment and Way Forward," Investment for Development Policy Research Series.

United Nations, 2015, “The World's Women 2015," Department of Economic and Social Affairs, United Nations, New York.

Vijaya R. M. and L. Kaltani, 2007, "Foreign Direct Investment and Wages: A Bargaining Power Approach," Journal of World-Systems Research, Vol. 13, No. 1, pp. 83-95.

World Bank, 2012, "World Development Report, Gender Equality and Development". The World Bank Group, Washington D.C. 
IAppendix II. List of Countries

\begin{tabular}{|c|c|c|}
\hline Afghanistan & Ghana & Namibia \\
\hline Albania & Guatemala & Nepal \\
\hline Algeria & Guinea & Nicaragua \\
\hline Argentina & Guyana & Niger \\
\hline Armenia & Honduras & Pakistan \\
\hline Azerbaijan & Hungary & Panama \\
\hline Bangladesh & India & Paraguay \\
\hline Belarus & Indonesia & Peru \\
\hline Belize & Iran & Philippines \\
\hline Benin & Iraq & Romania \\
\hline Bolivia & Jamaica & Rwanda \\
\hline Botswana & Jordan & Senegal \\
\hline Bulgaria & Kazakhstan & Serbia \\
\hline Burundi & Kenya & Sierra Leone \\
\hline Cambodia & Kyrgyz Republic & South Africa \\
\hline Cameroon & Lao people's Democratic Republic & Sri lanka \\
\hline Central African Republic & Lebanon & Sudan \\
\hline Chad & Lesotho & Suriname \\
\hline People's Republic of China & Liberia & Swaziland \\
\hline Colombia & Libya & Syrian Arab Republic \\
\hline Democratic Republic of the Congo & Republic of Macedonia & Tajikistan \\
\hline Republic of the Congo & Malawi & Tanzania \\
\hline Costa Rica & Malaysia & Thailand \\
\hline Cote d'ivoire & Maldives & Togo \\
\hline Dominican Republic & Mali & Tonga \\
\hline Ecuador & Mauritania & Tunisia \\
\hline Egypt & Mauritius & Turkey \\
\hline El Salvador & Mexico & Uganda \\
\hline Ethiopia & Moldova & Ukraine \\
\hline Fiji & Mongolia & Venezuela \\
\hline The Gambia & Morocco & West Bank and Gaza \\
\hline Georgia & Mozambique & Yemen \\
\hline
\end{tabular}




\section{Appendix III. Summary Statistics}

\begin{tabular}{|c|c|c|c|c|c|c|}
\hline \multirow{2}{*}{ Variables } & \multirow{2}{*}{ Sources } & \multicolumn{5}{|c|}{ Full sample } \\
\hline & & Obs & Mean & Std. Dev. & Min & Max \\
\hline Log(FDI inflows) & IMF STA database & 1663 & 3.6 & 1.9 & -7.3 & 10.8 \\
\hline Log(FDI inflows) & IMF WEO database & 1310 & 3.5 & 1.9 & -5.5 & 7.4 \\
\hline Log(FDI inflows) & UN database & 1903 & 3.4 & 1.9 & -4.6 & 7.4 \\
\hline GDI & UNDP & 2031 & 0.9 & 0.1 & 0.5 & 1.1 \\
\hline GII & UNDP & 1844 & 0.5 & 0.1 & 0.1 & 0.8 \\
\hline GDP growth rate & IMF WEO database & 1943 & 0.1 & 0.2 & -2.3 & 2.0 \\
\hline Log(trade openness) & World Bank & 1967 & 4.2 & 0.7 & -3.9 & 5.8 \\
\hline Polity 2 & Polity IV Series & 1938 & 2.6 & 6.0 & -9.0 & 10.0 \\
\hline $\log ($ public debt) & IMF WEO database & 1571 & 3.8 & 0.7 & -2.4 & 6.6 \\
\hline $\begin{array}{l}\text { Female population (in percentage of } \\
\text { total population) }\end{array}$ & World Bank & 2031 & 50.3 & 1.0 & 46.3 & 53.8 \\
\hline $\begin{array}{l}\text { Government expenditures (in } \\
\text { percentage of GDP) }\end{array}$ & IMF WEO database & 1772 & 26.6 & 9.2 & 4.3 & 105.3 \\
\hline $\begin{array}{l}\text { Natural resources rents (in percentage } \\
\text { of GDP) }\end{array}$ & World Bank & 1986 & 8.9 & 11.3 & 0.0 & 66.5 \\
\hline $\begin{array}{l}\text { Rural population (in percentage of } \\
\text { total population) }\end{array}$ & World Bank & 2031 & 54.2 & 20.1 & 8.2 & 94.6 \\
\hline Female life expectancy & $\begin{array}{l}\text { World Bank Gender } \\
\text { Statistics database }\end{array}$ & 1985 & 66.8 & 10.2 & 30.0 & 82.1 \\
\hline Average female year of schooling & $\begin{array}{l}\text { World Bank Gender } \\
\text { Statistics database }\end{array}$ & 1934 & 5.7 & 2.7 & 0.8 & 10.6 \\
\hline $\begin{array}{l}\text { Log(gross national income per } \\
\text { capita) }\end{array}$ & UNDP & 2031 & 8.1 & 0.9 & 6.0 & 9.7 \\
\hline $\begin{array}{l}\text { Maternity mortality ratio (per } \\
100,000 \text { live births) }\end{array}$ & $\begin{array}{l}\text { World Bank Gender } \\
\text { Statistics database }\end{array}$ & 2031 & 322.4 & 363.0 & 7.0 & 2900.0 \\
\hline $\begin{array}{l}\text { Gross enrolment in secondary level } \\
\text { (gender parity index) }\end{array}$ & $\begin{array}{l}\text { United Nations } \\
\text { database }\end{array}$ & 1323 & 0.9 & 0.2 & 0.2 & 1.6 \\
\hline Female share of parliamentary seats & $\begin{array}{l}\text { World Bank Gender } \\
\text { Statistics database }\end{array}$ & 1553 & 15.1 & 10.3 & 0.0 & 63.8 \\
\hline $\begin{array}{l}\text { Female to male labor participation } \\
\text { rate ratio }\end{array}$ & $\begin{array}{l}\text { International Labour } \\
\text { Organization }\end{array}$ & 1932 & 66.6 & 23.9 & 14.0 & 108.1 \\
\hline $\begin{array}{l}\text { Female to male ratio of employers (in } \\
\text { percentage of employment) }\end{array}$ & $\begin{array}{l}\text { World Bank Gender } \\
\text { Statistics database }\end{array}$ & 655 & 0.4 & 0.2 & 0.0 & 1.9 \\
\hline $\begin{array}{l}\text { Female informal employment (in } \\
\text { percentage of total employment) }\end{array}$ & $\begin{array}{l}\text { International Labour } \\
\text { Organization }\end{array}$ & 766 & 55.9 & 21.4 & 4.2 & 89.2 \\
\hline
\end{tabular}




\begin{tabular}{|c|c|c|c|c|c|c|}
\hline Variables & Sources & Obs. & Mean & Std. Dev. & Min & Max \\
\hline $\begin{array}{l}\text { Female to male ratio of part-time } \\
\text { employment (in percentage of total } \\
\text { employment) }\end{array}$ & $\begin{array}{l}\text { World Bank Gender } \\
\text { Statistics database }\end{array}$ & & & & & \\
\hline & & 811 & 2.1 & 0.9 & 1.1 & 5.3 \\
\hline Gender wage gap & $\begin{array}{l}\text { International Labour } \\
\text { Organization }\end{array}$ & 962 & 16.6 & 14.3 & -27.7 & 47.2 \\
\hline Gender budgeting dummy & $\begin{array}{l}\text { IMF Gender } \\
\text { budgeting portal }\end{array}$ & 2021 & 0.3 & 0.4 & 0.0 & 1.0 \\
\hline Equal wage law dummy & $\begin{array}{l}\text { World Bank Gender } \\
\text { Statistics database }\end{array}$ & 1353 & 0.1 & 0.3 & 0.0 & 1.0 \\
\hline $\begin{array}{l}\text { Non-discrimination in hiring law } \\
\text { dummy }\end{array}$ & $\begin{array}{l}\text { World Bank Gender } \\
\text { Statistics database }\end{array}$ & 1449 & 0.2 & 0.4 & 0.0 & 1.0 \\
\hline Female access to resources & $\begin{array}{l}\text { OECD - Gender, } \\
\text { Institutions and } \\
\text { Development }\end{array}$ & 1945 & 0.4 & 0.2 & 0.0 & 1.0 \\
\hline $\begin{array}{l}\text { Log(FDI inflows in percentage of } \\
\text { GDP) }\end{array}$ & IMF STA database & 1227 & -3.9 & 1.6 & -16.8 & -0.2 \\
\hline $\begin{array}{l}\text { Log(FDI inflows in percentage of } \\
\text { GDP) }\end{array}$ & IMF WEO database & 1095 & -3.5 & 0.8 & -4.6 & -0.2 \\
\hline $\begin{array}{l}\text { Log(FDI inflows in percentage of } \\
\text { GDP) }\end{array}$ & $\begin{array}{l}\text { United Nations } \\
\text { database }\end{array}$ & 1907 & 0.7 & 1.3 & -4.6 & 4.0 \\
\hline
\end{tabular}




\section{Appendix IV. Robustness Test 1}

8Table 9. Robustness Checks: Using WEO and United Nations Data on FDI

\begin{tabular}{|c|c|c|c|c|c|c|c|c|}
\hline & $(1)$ & $(2)$ & $(3)$ & (4) & $(5)$ & $(6)$ & $(7)$ & $(8)$ \\
\hline & \multicolumn{4}{|c|}{ Using WEO data } & \multicolumn{4}{|c|}{ Using United Nations data } \\
\hline VARIABLES & $(\mathrm{GDI})$ & (GII) & $(\mathrm{GDI})$ & (GII) & (GDI) & (GII) & $(\mathrm{GDI})$ & (GII) \\
\hline \multirow[t]{2}{*}{ Log (FDI inflows) } & $0.00314 * * *$ & $-0.00372 * * *$ & $0.00275^{* * *}$ & $-0.00327 * * *$ & $0.00289^{* * *}$ & $-0.00329^{* * *}$ & $0.00269^{* * *}$ & $-0.00310^{* * *}$ \\
\hline & $(0.0007)$ & $(0.0012)$ & $(0.0006)$ & $(0.0012)$ & $(0.0006)$ & $(0.0010)$ & $(0.0006)$ & $(0.0010)$ \\
\hline \multirow[t]{2}{*}{ GDP growth } & 0.00524 & 0.0125 & 0.00705 & 0.0114 & 0.00405 & 0.00763 & 0.00526 & 0.00666 \\
\hline & $(0.0056)$ & $(0.0104)$ & $(0.0055)$ & $(0.0104)$ & $(0.0047)$ & $(0.0079)$ & $(0.0047)$ & $(0.0080)$ \\
\hline \multirow[t]{2}{*}{ Log(trade openness) } & $0.00738^{* *}$ & 0.0092 & $0.00851^{* *}$ & 0.00588 & $0.0110^{* * *}$ & 0.000977 & $0.0102 * * *$ & -0.00122 \\
\hline & $(0.0033)$ & $(0.0063)$ & $(0.0035)$ & $(0.0065)$ & $(0.0029)$ & $(0.0048)$ & $(0.0029)$ & $(0.0049)$ \\
\hline \multirow[t]{2}{*}{ Polity2 } & $0.00130 * * *$ & $-0.000957^{*}$ & $0.00107 * * *$ & -0.000813 & 0.000133 & $-0.000843^{* *}$ & 5.63E-06 & $-0.000890 * *$ \\
\hline & $(0.0003)$ & $(0.0005)$ & $(0.0003)$ & $(0.0005)$ & $(0.0002)$ & $(0.0004)$ & $(0.0002)$ & $(0.0004)$ \\
\hline \multirow[t]{2}{*}{ Log(public debt) } & $-0.00649 * * *$ & $0.00762 * * *$ & $-0.00742 * * *$ & $0.00755^{* * *}$ & $-0.00614 * * *$ & 0.00302 & $-0.00626^{* * *}$ & $0.00346^{*}$ \\
\hline & $(0.0012)$ & $(0.0023)$ & $(0.0012)$ & $(0.0023)$ & $(0.0011)$ & $(0.0019)$ & $(0.0011)$ & $(0.0019)$ \\
\hline \multirow[t]{2}{*}{ Female population } & & & $0.00523 * * *$ & $-0.0145^{* * *}$ & & & $0.00625 * * *$ & $-0.0125 * * *$ \\
\hline & & & $(0.0018)$ & $(0.0035)$ & & & $(0.0017)$ & $(0.0029)$ \\
\hline \multirow[t]{2}{*}{ Government expenditures } & & & $0.000733^{* * *}$ & 0.000322 & & & $0.000731^{* * *}$ & 0.000189 \\
\hline & & & $(0.0002)$ & $(0.0003)$ & & & $(0.0001)$ & $(0.0002)$ \\
\hline \multirow[t]{2}{*}{ Natural resources rents } & & & -0.00025 & 0.000394 & & & 0.000103 & 0.000269 \\
\hline & & & $(0.0002)$ & $(0.0003)$ & & & $(0.0001)$ & $(0.0002)$ \\
\hline \multirow[t]{2}{*}{ Rural population } & & & $0.000577 * *$ & $-0.00150 * * *$ & & & -0.000187 & -0.00018 \\
\hline & & & $(0.0003)$ & $(0.0005)$ & & & $(0.0002)$ & $(0.0004)$ \\
\hline \multirow[t]{2}{*}{ Constant } & $0.593 * * *$ & $0.623 * * *$ & $0.276^{* * *}$ & $1.441 * * *$ & $0.580 * * *$ & $0.663 * * *$ & $0.275^{* * *}$ & $1.286^{* * *}$ \\
\hline & $(0.0172)$ & $(0.0319)$ & $(0.0946)$ & $(0.1760)$ & $(0.0160)$ & $(0.0268)$ & $(0.0879)$ & $(0.1480)$ \\
\hline Observations & 973 & 973 & 960 & 960 & 1,267 & 1,267 & 1,253 & 1,253 \\
\hline R-squared & 0.972 & 0.963 & 0.973 & 0.964 & 0.966 & 0.962 & 0.967 & 0.963 \\
\hline Country-fixed effects & YES & YES & YES & YES & YES & YES & YES & YES \\
\hline Year-fixed effects & YES & YES & YES & YES & YES & YES & YES & YES \\
\hline
\end{tabular}




\section{Appendix V. Robustness Test 2}

Table 10. Robustness Checks: Using Alternative Econometric Method

\begin{tabular}{|c|c|c|c|c|}
\hline & $(1)$ & (2) & (3) & $(4)$ \\
\hline Dependent variables & (GDI) & (GII) & (GDI) & (GII) \\
\hline \multirow[t]{2}{*}{ Log(FDI inflows) } & $0.00606 * * *$ & $-0.00478 * *$ & $0.00570 * * *$ & $-0.00515 * *$ \\
\hline & $(0.0011)$ & $(0.0020)$ & $(0.0011)$ & $(0.0020)$ \\
\hline \multirow[t]{2}{*}{ GDP growth } & 0.0042 & 0.00867 & 0.00479 & 0.00706 \\
\hline & $(0.0048)$ & $(0.0089)$ & $(0.0047)$ & $(0.0089)$ \\
\hline \multirow[t]{2}{*}{ Log(trade openness) } & $0.00560 *$ & $-0.0114 * *$ & $0.00534^{*}$ & $-0.0174 * * *$ \\
\hline & $(0.0028)$ & $(0.0051)$ & $(0.0029)$ & $(0.0053)$ \\
\hline \multirow[t]{2}{*}{ Polity2 } & $0.000868 * * *$ & 0.000146 & $0.000732 * * *$ & -0.000121 \\
\hline & $(0.0002)$ & $(0.0004)$ & $(0.0002)$ & $(0.0004)$ \\
\hline \multirow[t]{2}{*}{$\log ($ public debt) } & $-0.00324 * * *$ & $0.00348 *$ & $-0.00338 * * *$ & $0.00435 * *$ \\
\hline & $(0.0011)$ & $(0.0020)$ & $(0.0011)$ & $(0.0021)$ \\
\hline \multirow[t]{2}{*}{ Female population } & & & -0.00124 & $-0.0105 * * *$ \\
\hline & & & $(0.0017)$ & $(0.0032)$ \\
\hline \multirow[t]{2}{*}{ Government expenditures } & & & $0.000632 * * *$ & $0.000549 * *$ \\
\hline & & & $(0.0001)$ & $(0.0003)$ \\
\hline \multirow[t]{2}{*}{ Natural resources rents } & & & -0.000114 & $0.000785 * * *$ \\
\hline & & & $(0.0002)$ & $(0.0003)$ \\
\hline \multirow[t]{2}{*}{ Rural population } & & & -0.000124 & -0.000452 \\
\hline & & & $(0.0002)$ & $(0.0004)$ \\
\hline \multirow[t]{2}{*}{ Constant } & $0.589 * * *$ & $0.714 * * *$ & $0.644 * * *$ & $1.264 * * *$ \\
\hline & $(0.0147)$ & $(0.0274)$ & $(0.0826)$ & $(0.1590)$ \\
\hline Observations & 1,111 & 1,211 & 1,100 & 1,193 \\
\hline R-squared & 0.972 & 0.96 & 0.974 & 0.962 \\
\hline Country-fixed effects & YES & YES & YES & YES \\
\hline Year-fixed effects & YES & YES & YES & YES \\
\hline
\end{tabular}




\section{Appendix VI. Robustness Test 3}

Table 11. Robustness Checks: Including Additional Control Variables

\begin{tabular}{|c|c|c|c|c|}
\hline & $(1)$ & (2) & (3) & (4) \\
\hline Dependent variables & $(\mathrm{GDI})$ & (GII) & (GDI) & (GII) \\
\hline Log(FDI inflows) & $\begin{array}{l}0.00356 * * * \\
(0.0005)\end{array}$ & $\begin{array}{l}-0.00218^{* *} \\
(0.0009)\end{array}$ & $\begin{array}{l}0.00354 * * * \\
(0.0005)\end{array}$ & $\begin{array}{l}-0.00214^{* *} \\
(0.0009)\end{array}$ \\
\hline GDP growth & $\begin{array}{l}0.00635 \\
(0.0050)\end{array}$ & $\begin{array}{l}0.0136 \\
(0.0089)\end{array}$ & $\begin{array}{l}0.00632 \\
(0.0051)\end{array}$ & $\begin{array}{l}0.0143 \\
(0.0090)\end{array}$ \\
\hline Log(trade openness) & $\begin{array}{l}0.0104 * * * \\
(0.0030)\end{array}$ & $\begin{array}{l}-0.00394 \\
(0.0054)\end{array}$ & $\begin{array}{l}0.0105 * * * \\
(0.0030)\end{array}$ & $\begin{array}{l}-0.00450 \\
(0.0054)\end{array}$ \\
\hline Polity2 & $\begin{array}{l}0.000881 * * * \\
(0.0003)\end{array}$ & $\begin{array}{l}-0.000902 * * \\
(0.0005)\end{array}$ & $\begin{array}{l}0.000878 * * * \\
(0.0003)\end{array}$ & $\begin{array}{l}-0.000895 * \\
(0.0005)\end{array}$ \\
\hline Log(public debt) & $\begin{array}{l}-0.00556 * * * \\
(0.0011)\end{array}$ & $\begin{array}{l}0.00569 * * * \\
(0.0020)\end{array}$ & $\begin{array}{l}-0.00553 * * * \\
(0.0011)\end{array}$ & $\begin{array}{l}0.00559 * * * \\
(0.0021)\end{array}$ \\
\hline Female population & $\begin{array}{l}0.00388 * * \\
(0.0017)\end{array}$ & $\begin{array}{l}-0.0110 * * * \\
(0.0031)\end{array}$ & $\begin{array}{l}0.00387 * * \\
(0.0017)\end{array}$ & $\begin{array}{l}-0.0109 * * * \\
(0.0031)\end{array}$ \\
\hline Government expenditure & $\begin{array}{l}0.000658 * * * \\
(0.0001)\end{array}$ & $\begin{array}{l}0.000231 \\
(0.0003)\end{array}$ & $\begin{array}{l}0.000658^{* * * *} \\
(0.0001)\end{array}$ & $\begin{array}{l}0.000236 \\
(0.0003)\end{array}$ \\
\hline Natural resources rents & $\begin{array}{l}-0.000231 \\
(0.0002)\end{array}$ & $\begin{array}{l}0.000875 * * * \\
(0.0003)\end{array}$ & $\begin{array}{l}-0.000232 \\
(0.0002)\end{array}$ & $\begin{array}{l}0.000870 * * * \\
(0.0003)\end{array}$ \\
\hline Rural population & $\begin{array}{l}-5.25 e-05 \\
(0.0002)\end{array}$ & $\begin{array}{l}-0.000432 \\
(0.0004)\end{array}$ & $\begin{array}{l}-4.34 \mathrm{e}-05 \\
(0.0002)\end{array}$ & $\begin{array}{l}-0.000470 \\
(0.0004)\end{array}$ \\
\hline Ethnic diversity & $\begin{array}{l}-0.689 * * * \\
(0.0235)\end{array}$ & $\begin{array}{l}0.723 * * * \\
(0.0419)\end{array}$ & & \\
\hline Islam & & & $\begin{array}{l}-0.256^{* * *} \\
(0.0242)\end{array}$ & $\begin{array}{l}0.418 * * * \\
(0.0430)\end{array}$ \\
\hline Catholicism & & & $\begin{array}{l}0.0421 * * * \\
(0.0121)\end{array}$ & $\begin{array}{l}0.0850 * * * \\
(0.0215)\end{array}$ \\
\hline Protestantism & & & $\begin{array}{l}0.487 * * \\
(0.2220)\end{array}$ & $\begin{array}{l}1.682 * * * \\
(0.3950)\end{array}$ \\
\hline Hinduism & & & $\begin{array}{l}-15.62 * * * \\
(3.2050)\end{array}$ & $\begin{array}{l}-7.012 \\
(5.6960)\end{array}$ \\
\hline Buddhism & & & $\begin{array}{l}0.0312 \\
(0.0260)\end{array}$ & $\begin{array}{l}-0.0547 \\
(0.0462)\end{array}$ \\
\hline Constant & $\begin{array}{l}0.853 * * * \\
(0.0910)\end{array}$ & $\begin{array}{l}0.835 * * * \\
(0.1620)\end{array}$ & $\begin{array}{l}0.667 * * * \\
(0.0939)\end{array}$ & $\begin{array}{l}1.026^{* * *} \\
(0.1670)\end{array}$ \\
\hline Observations & 1,146 & 1,146 & 1,138 & 1,138 \\
\hline R-squared & 0.970 & 0.963 & 0.970 & 0.962 \\
\hline Country-fixed effects & YES & YES & YES & YES \\
\hline Year-fixed effects & YES & YES & YES & YES \\
\hline
\end{tabular}




\section{Appendix VII. Robustness Test 4}

Table 12. Robustness Checks: Using FDI in Percentage of GDP Instead of FDI Per Capita

\begin{tabular}{|c|c|c|c|c|c|c|c|c|c|c|c|c|}
\hline & (1) & $(2)$ & (3) & (4) & (5) & (6) & $(7)$ & $(8)$ & (9) & $(10)$ & $(11)$ & $(12)$ \\
\hline & \multicolumn{4}{|c|}{ Data source: IMF's STA } & \multicolumn{4}{|c|}{ Data source: IMF's WEO } & \multicolumn{4}{|c|}{ Data source: United Nations } \\
\hline Dependent variables & (GDI) & (GII) & (GDI) & (GII) & (GDI) & (GII) & $(\mathrm{GDI})$ & (GII) & (GDI) & (GII) & $(\mathrm{GDI})$ & (GII) \\
\hline Log(FDI inflows) & $\begin{array}{l}0.00404 * * * \\
(0.0006)\end{array}$ & $\begin{array}{l}-0.00350^{* * *} \\
(0.0012)\end{array}$ & $\begin{array}{l}0.00381 * * * \\
(0.0006)\end{array}$ & $\begin{array}{l}-0.00310^{* *} \\
(0.0012)\end{array}$ & $\begin{array}{l}0.00306^{* * *} \\
(0.0009)\end{array}$ & $\begin{array}{l}-0.00473 * * \\
(0.0018)\end{array}$ & $\begin{array}{l}0.00247 * * \\
(0.0009)\end{array}$ & $\begin{array}{l}-0.00486^{* * *} \\
(0.0018)\end{array}$ & $\begin{array}{l}0.00348 * * * \\
(0.0006)\end{array}$ & $\begin{array}{l}-0.00335^{* * *} \\
(0.0010)\end{array}$ & $\begin{array}{l}0.00341^{* * *} \\
(0.0006)\end{array}$ & $\begin{array}{l}-0.00328 \text { *** } \\
(0.0010)\end{array}$ \\
\hline GDP growth & $\begin{array}{l}0.00805 \\
(0.0060)\end{array}$ & $\begin{array}{l}0.011 \\
(0.0112)\end{array}$ & $\begin{array}{l}0.0103 * \\
(0.0059)\end{array}$ & $\begin{array}{l}0.00866 \\
(0.0112)\end{array}$ & $\begin{array}{l}0.00255 \\
(0.0058)\end{array}$ & $\begin{array}{l}0.0109 \\
(0.0112)\end{array}$ & $\begin{array}{l}0.00421 \\
(0.0057)\end{array}$ & $\begin{array}{l}0.00803 \\
(0.0111)\end{array}$ & $\begin{array}{l}0.00507 \\
(0.0047)\end{array}$ & $\begin{array}{l}0.00635 \\
(0.0079)\end{array}$ & $\begin{array}{l}0.00618 \\
(0.0047)\end{array}$ & $\begin{array}{l}0.00538 \\
(0.0080)\end{array}$ \\
\hline Log(trade openness) & $\begin{array}{l}0.00302 \\
(0.0036)\end{array}$ & $\begin{array}{l}0.0133 * * \\
(0.0066)\end{array}$ & $\begin{array}{l}0.004 \\
(0.0037)\end{array}$ & $\begin{array}{l}0.00999 \\
(0.0070)\end{array}$ & $\begin{array}{l}0.00527 \\
(0.0036)\end{array}$ & $\begin{array}{l}0.00912 \\
(0.0068)\end{array}$ & $\begin{array}{l}0.00497 \\
(0.0037)\end{array}$ & $\begin{array}{l}0.00569 \\
(0.0072)\end{array}$ & $\begin{array}{l}0.00978^{* * * *} \\
(0.0029)\end{array}$ & $\begin{array}{l}0.0018 \\
(0.0048)\end{array}$ & $\begin{array}{l}0.00896 * * * \\
(0.0029)\end{array}$ & $\begin{array}{l}-0.00034 \\
(0.0050)\end{array}$ \\
\hline Polity2 & $\begin{array}{l}0.00123 * * * \\
(0.0003)\end{array}$ & $\begin{array}{l}-0.000845^{*} \\
(0.0005)\end{array}$ & $\begin{array}{l}0.000976^{* * *} \\
(0.0003)\end{array}$ & $\begin{array}{l}-0.000721 \\
(0.0005)\end{array}$ & $\begin{array}{l}0.000792^{* * *} \\
(0.0003)\end{array}$ & $\begin{array}{l}-0.000639 \\
(0.0006)\end{array}$ & $\begin{array}{l}0.000609^{* *} \\
(0.0003)\end{array}$ & $\begin{array}{l}-0.000339 \\
(0.0005)\end{array}$ & $\begin{array}{l}0.000124 \\
(0.0002)\end{array}$ & $\begin{array}{l}-0.000840 * * \\
(0.0004)\end{array}$ & $\begin{array}{l}-3.52 \mathrm{E}-06 \\
(0.0002)\end{array}$ & $\begin{array}{l}-0.000887^{* *} \\
(0.0004)\end{array}$ \\
\hline $\log$ (public debt) & $\begin{array}{l}-0.00516^{* * *} \\
(0.0012)\end{array}$ & $\begin{array}{l}0.00701 * * * \\
(0.0024)\end{array}$ & $\begin{array}{l}-0.00597^{* * *} \\
(0.0013)\end{array}$ & $\begin{array}{l}0.00691 \text { *** } \\
(0.0024)\end{array}$ & $\begin{array}{l}-0.00755^{* * *} \\
(0.0015)\end{array}$ & $\begin{array}{l}0.00683^{* *} \\
(0.0029)\end{array}$ & $\begin{array}{l}-0.00840^{* * *} \\
(0.0015)\end{array}$ & $\begin{array}{l}0.00635^{* *} \\
(0.0029)\end{array}$ & $\begin{array}{l}-0.00606^{* * *} \\
(0.0011)\end{array}$ & $\begin{array}{l}0.00314^{*} \\
(0.0019)\end{array}$ & $\begin{array}{l}-0.00614^{* * *} \\
(0.0011)\end{array}$ & $\begin{array}{l}0.00355^{*} \\
(0.0019)\end{array}$ \\
\hline Female population & & & $\begin{array}{l}0.00662 * * * \\
(0.0019)\end{array}$ & $\begin{array}{l}-0.0175^{* * *} \\
(0.0036)\end{array}$ & & & $\begin{array}{l}0.00483^{* *} \\
(0.0019)\end{array}$ & $\begin{array}{l}-0.0114 * * * \\
(0.0037)\end{array}$ & & & $\begin{array}{l}0.00636^{* * *} \\
(0.0017)\end{array}$ & $\begin{array}{l}-0.0127 * * * \\
(0.0029)\end{array}$ \\
\hline Government expenditure & & & $\begin{array}{l}0.000762 * * * \\
(0.0002)\end{array}$ & $\begin{array}{l}0.000201 \\
(0.0003)\end{array}$ & & & $\begin{array}{l}0.000804^{* * *} \\
(0.0002)\end{array}$ & $\begin{array}{l}1.84 \mathrm{E}-05 \\
(0.0003)\end{array}$ & & & $\begin{array}{l}0.000733^{* * *} \\
(0.0001)\end{array}$ & $\begin{array}{l}0.00018 \\
(0.0002)\end{array}$ \\
\hline Natural resources rents & & & $\begin{array}{l}-0.000269 \\
(0.0002)\end{array}$ & $\begin{array}{l}0.000406 \\
(0.0004)\end{array}$ & & & $\begin{array}{l}-1.24 \mathrm{E}-06 \\
(0.0002)\end{array}$ & $\begin{array}{l}0.000603 \\
(0.0004)\end{array}$ & & & $\begin{array}{l}0.000105 \\
(0.0001)\end{array}$ & $\begin{array}{l}0.000276 \\
(0.0002)\end{array}$ \\
\hline Rural population & & & $\begin{array}{l}0.000687^{* *} \\
(0.0003)\end{array}$ & $\begin{array}{l}-0.00154^{* * *} \\
(0.0005)\end{array}$ & & & $\begin{array}{l}0.000354 \\
(0.0003)\end{array}$ & $\begin{array}{l}-0.00193^{* * *} \\
(0.0005)\end{array}$ & & & $\begin{array}{l}-0.000237 \\
(0.0002)\end{array}$ & $\begin{array}{l}-0.000132 \\
(0.0004)\end{array}$ \\
\hline Constant & $\begin{array}{l}0.633 * * * \\
(0.0188)\end{array}$ & $\begin{array}{l}0.583 * * * \\
(0.0350)\end{array}$ & $\begin{array}{l}0.239 * * \\
(0.0967)\end{array}$ & $\begin{array}{l}1.556 * * * \\
(0.1810)\end{array}$ & $\begin{array}{l}0.621 * * * \\
(0.0191)\end{array}$ & $\begin{array}{l}0.599 * * * \\
(0.0368)\end{array}$ & $\begin{array}{l}0.340^{* * *} \\
(0.0952)\end{array}$ & $\begin{array}{l}1.307 * * * \\
(0.1840)\end{array}$ & $\begin{array}{l}0.590^{* * *} \\
(0.0161)\end{array}$ & $\begin{array}{l}0.653 * * * \\
(0.0271)\end{array}$ & $\begin{array}{l}0.284 * * * \\
(0.0875)\end{array}$ & $\begin{array}{l}1.279 * * * \\
(0.1480)\end{array}$ \\
\hline Observations & 899 & 899 & 890 & 890 & 882 & 882 & 872 & 872 & 1,269 & 1,269 & 1,255 & 1,255 \\
\hline R-squared & 0.972 & 0.962 & 0.974 & 0.964 & 0.974 & 0.964 & 0.975 & 0.965 & 0.967 & 0.963 & 0.968 & 0.963 \\
\hline Country-fixed effects & YES & YES & YES & YES & YES & YES & YES & YES & YES & YES & YES & YES \\
\hline Year-fixed effects & YES & YES & YES & YES & YES & YES & YES & YES & YES & YES & YES & YES \\
\hline
\end{tabular}




\section{Appendix VIII. Robustness Test 5}

Table 13. Robustness Checks: Using Alternative Dependent Variables

\begin{tabular}{|c|c|c|c|c|}
\hline & (1) & (2) & (3) & (4) \\
\hline Dependent Variables & $(\mathrm{GDI})$ & (GII) & (GDI) & (GII) \\
\hline $\log$ (FDI inflows) & $\begin{array}{l}0.0036^{* * *} \\
(0.0005)\end{array}$ & $\begin{array}{l}-0.0024^{* *} \\
(0.0009)\end{array}$ & $\begin{array}{l}0.0033^{* * *} \\
(0.0005)\end{array}$ & $\begin{array}{l}-0.0020^{* *} \\
(0.0009)\end{array}$ \\
\hline GDP growth & $\begin{array}{l}0.000387 \\
(0.0049)\end{array}$ & $\begin{array}{l}0.0124 \\
(0.0093)\end{array}$ & $\begin{array}{l}0.0026 \\
(0.0049)\end{array}$ & $\begin{array}{l}0.0098 \\
(0.0093)\end{array}$ \\
\hline Log(trade openness) & $\begin{array}{l}0.0064^{* *} \\
(0.0030)\end{array}$ & $\begin{array}{l}-0.0009 \\
(0.0056)\end{array}$ & $\begin{array}{l}0.0092^{* * *} \\
(0.0031)\end{array}$ & $\begin{array}{l}-0.0066 \\
(0.0057)\end{array}$ \\
\hline Polity2 & $\begin{array}{l}0.0008^{* * * *} \\
(0.0003)\end{array}$ & $\begin{array}{l}-0.0010^{* *} \\
(0.0005)\end{array}$ & $\begin{array}{l}0.0007 * * * \\
(0.0003)\end{array}$ & $\begin{array}{l}-0.0011^{* *} \\
(0.0005)\end{array}$ \\
\hline $\log ($ public debt) & $\begin{array}{l}-0.0046^{* * *} \\
(0.0011)\end{array}$ & $\begin{array}{l}0.0065^{* * *} \\
(0.0021)\end{array}$ & $\begin{array}{l}-0.0053^{* * *} \\
(0.0011)\end{array}$ & $\begin{array}{l}0.0076^{* * *} \\
(0.0021)\end{array}$ \\
\hline Female population & & & $\begin{array}{l}0.0074 * * * \\
(0.0020)\end{array}$ & $\begin{array}{l}-0.0155^{* * *} \\
(0.0038)\end{array}$ \\
\hline Government expenditure & & & $\begin{array}{l}0.0006^{* * *} \\
(0.0001)\end{array}$ & $\begin{array}{l}0.0002 \\
(0.0003)\end{array}$ \\
\hline Natural resources rents & & & $\begin{array}{l}-0.0004^{* *} \\
(0.0002)\end{array}$ & $\begin{array}{l}0.0008^{* * *} \\
(0.0003)\end{array}$ \\
\hline Rural population & & & $\begin{array}{l}0.0001 \\
(0.0003)\end{array}$ & $\begin{array}{l}-0.0003 \\
(0.0005)\end{array}$ \\
\hline Constant & $\begin{array}{l}0.8780^{* * *} \\
(0.0140)\end{array}$ & $\begin{array}{l}0.4110^{* * *} \\
(0.0262)\end{array}$ & $\begin{array}{l}0.4800^{* * * *} \\
(0.1020)\end{array}$ & $\begin{array}{l}1.2050^{* * *} \\
(0.1910)\end{array}$ \\
\hline Observations & 1,039 & 1,039 & 1,029 & 1,029 \\
\hline R-squared & 0.973 & 0.963 & 0.974 & 0.964 \\
\hline Country-fixed effects & YES & YES & YES & YES \\
\hline Year-fixed effects & YES & YES & YES & YES \\
\hline
\end{tabular}

Standard errors in parentheses. ${ }^{* * *} \mathrm{p}<0.01$, significant at $1 \% ;{ }^{* *} \mathrm{p}<0.05$, significant at $5 \% ;{ }^{*} \mathrm{p}<0.1$, significant at $10 \%$ 